\title{
Abca1 Deficiency Affects Alzheimer's Disease-Like Phenotype in Human ApoE4 But Not in ApoE3-Targeted Replacement Mice
}

\author{
Nicholas F. Fitz, ${ }^{1 \star}$ Andrea A. Cronican, ${ }^{1 \star}$ Muzamil Saleem, ${ }^{1}$ Abdul H. Fauq, ${ }^{2}$ Robert Chapman, ${ }^{2}$ Iliya Lefterov, ${ }^{1}$ \\ and Radosveta Koldamova ${ }^{1}$ \\ ${ }^{1}$ Department of Environmental and Occupational Health, University of Pittsburgh, Pittsburgh, Pennsylvania 15219, and ${ }^{2}$ Chemical Synthesis Core Facility, \\ Mayo Clinic Jacksonville, Jacksonville, Florida 32224
}

ATP-binding cassette transporter A1 (ABCA1) transporter regulates cholesterol efflux and is an essential mediator of high-density lipoprotein (HDL) formation. In amyloid precursor protein (APP) transgenic mice, Abcal deficiency increased amyloid deposition in the brain paralleled by decreased levels of Apolipoprotein E (ApoE). The APOE\&4 allele is the major genetic risk factor of sporadic Alzheimer's disease (AD). Here, we reveal the effect of Abcal deficiency on phenotype in mice expressing human ApoE3 or ApoE4. We used $\mathrm{APP} / \mathrm{E} 3$ and APP/E4 mice generated by crossing APP/PS1 $\triangle \mathrm{E} 9$ transgenic mice to human APOE3- and APOE4-targeted replacement mice and examined $\mathrm{Abcal}$ gene dose effect on amyloid deposition and cognition. The results from two behavior tests demonstrate that lack of one copy of $A b c a 1$ significantly exacerbates memory deficits in APP/E4/Abcal ${ }^{-/+}$but not in APP/E3/Abca1 ${ }^{-1+}$ mice. The data for amyloid plaques and insoluble amyloid- $\beta(\mathrm{A} \beta)$ also show that $A b c a 1$ hemizygosity increases $\mathrm{A} \beta$ deposition only in $\mathrm{APP} / \mathrm{E} 4 / \mathrm{Abcal}^{-/+}$ but not in $\mathrm{APP} / \mathrm{E} 3 / \mathrm{Abcal}^{-/+}$mice. Our in vivo microdialysis assays indicate that $A b c a 1$ deficiency significantly decreases $\mathrm{A} \beta$ clearance in ApoE4-expressing mice, while the effect of $A b c a 1$ on $\mathrm{A} \beta$ clearance in ApoE3-expressing mice was insignificant. In addition, we demonstrate that plasma $\mathrm{HDL}$ and $\mathrm{A} \beta 42$ levels in $\mathrm{APP} / \mathrm{E} 4 / \mathrm{Abca}{ }^{-1+}$ mice are significantly decreased, and there is a negative correlation between plasma HDL and amyloid plaques in brain, suggesting that plasma lipoproteins may be involved in $\mathrm{A} \beta$ clearance. Overall, our results prove that the presence of functional Abcal significantly influences the phenotype of APP mice expressing human ApoE4 and further substantiate therapeutic approaches in $\mathrm{AD}$ based on $\mathrm{ABCA1-APOE}$ regulatory axis.

\section{Introduction}

Alzheimer's disease (AD) is a late-onset dementia characterized by the presence of senile plaques made of amyloid- $\beta(A \beta)$, neurofibrillary tangles, and cognitive decline. Although the inheritance of $\varepsilon 4$ allele of Apolipoprotein $\mathrm{E}$ (APOE) is the major genetic risk factor for late-onset AD (Saunders et al., 1993), the mechanisms underlying this association remain elusive (Kim et al., 2009). It is important to note that, while the incidence of $A D$ among APOE4 allele carriers is substantially increased, not everybody with this allele develops the disease (Corder et al., 1993). It

\footnotetext{
Received April 20, 2012; revised June 18, 2012; accepted July 11, 2012.

Author contributions: N.F.F., I.L., and R.K. designed research; N.F.F., A.A.C., M.S., and R.K. performed research; A.H.F. and R.C. contributed unpublished reagents/analytic tools; N.F.F., A.A.C., M.S., and R.K. analyzed data; I.L. and R.K. wrote the paper.

${ }^{*}$ N.F.F. and A.A.C. contributed equally to this work.

This work was supported in part by NIH-NIA Grants R01AG027973 and R01AG037481 (R.K.), Institute for the Study of Aging grant (I.L.), and Alzheimer's Art Quilt Initiative Grant (N.F.F.). N.F.F. is supported by NIA F32 fellowship (Grant F32AG034031). We are grateful to Sai Pratyusha Kancherla, Hiral Jayantibhai Patel, and Xiaozhuo Lu for their excellent technical assistance. The content of this report is solely responsibility of the authors and does not necessarily represent the official views of the National Institute on Aging, National Institutes of Health, or the private foundations.

Correspondence should be addressed to Radosveta Koldamova, Department of Environmental and Occupational Health, University of Pittsburgh, 100 Technology Drive, Bridgeside Point, Pittsburgh, PA 15219. E-mail: radak@pitt.edu.

DOI:10.1523/JNEUROSCI.1937-12.2012

Copyright $(\odot) 2012$ the authors $\quad 0270-6474 / 12 / 3213125-12 \$ 15.00 / 0$
}

is conceivable that additional genetic factors influence the risk and precipitate the development of dementia.

ATP-binding cassette transporter A1 (ABCA1) is a lipid pump that regulates cholesterol and phospholipids efflux from cells to lipid-poor apolipoprotein A-I (ApoA-I) and ApoE in a process essential for the formation of high-density lipoproteins (HDLs) (Brooks-Wilson et al., 1999). We and others have shown that Abcal deficiency increased amyloid deposition in different $\mathrm{AD}$ model mice in parallel with reduced ApoE and ApoA-I levels (Hirsch-Reinshagen et al., 2005; Koldamova et al., 2005b; Wahrle et al., 2005). A recent report from our group also demonstrated that amyloid precursor protein (APP) mice with one functional copy of $A b c a 1$ have significant memory deficits that correlated with the levels of soluble $A \beta$ oligomers (Lefterov et al., 2009). In contrast, it has been shown that transgenic overexpression of ABCA1 (Wahrle et al., 2008) or treatments with liver X receptor (LXR) and retinoid X receptor (RXR) agonists (Koldamova et al., 2005a; Fitz et al., 2010; Cramer et al., 2012) ameliorate AD phenotype in APP transgenic mice. So far, the role of Abcal has been studied only in mice expressing mouse ApoE. Considering the risk for developing $\mathrm{AD}$ in association with $A P O E 4$ carrier status, the phenotypic characterization of $\mathrm{AD}$ animal model on human ApoE3 or ApoE4 background would be helpful to further understand the role of ABCA1 in the pathogenesis of the disease. APOE-targeted replacement mice expressing human ApoE iso- 
forms under the control of mouse promoter have been used to study the effect of human ApoE on AD-like phenotype (Sullivan et al., 1997). Two recent studies characterized the phenotype of PDAPP mice crossed to APOE-targeted replacement mice and demonstrated that APOE4-expressing mice have more amyloid and less APOE than the other two isoforms (Bales et al., 2009; Castellano et al., 2011). Moreover, it has been shown that, in APOE4 mice, $\mathrm{A} \beta$ clearance is significantly delayed (Castellano et al., 2011).

In this study, we used APP/PS1 $\triangle \mathrm{E} 9$ transgenic mice crossed to human APOE3- and APOE4-targeted replacement mice (APP/E3 and APP/E4, respectively). To examine the effect of Abcal deficiency, APP/E3 and APP/E4 were crossed to Abcal knock-out mice. Here, we compare amyloid deposition and cognitive decline in APP/E3 and APP/E4 mice expressing wild-type Abcal to Abcal hemizygous mice (APP/E3/Abca ${ }^{-1+}$ and APP/ E4/Abcal $\left.{ }^{-/+}\right)$. Unexpectedly, our results demonstrate that Abcal deficiency affected amyloid load and memory deficits only in APP/E4 but not in APP/E3 mice. Importantly, our data also suggest that the level of ApoE and HDL in plasma may affect $A \beta$ clearance.

\section{Materials and Methods}

\section{Materials}

All chemicals and plastics were purchased through Thermo Fisher Scientific, unless noted otherwise.

\section{Animals}

Mouse strains. The study fully conformed to the guidelines outlined in the Guide for the Care and Use of Laboratory Animals from the United States Department of Health and Human Services and was approved by the University of Pittsburgh Institutional Animal Care and Use Committee. APP/PS1 $\Delta$ E9 mice [B6.Cg-Tg (APPswe, PSEN1 $\Delta$ E9) 85Dbo/J] were purchased from The Jackson Laboratory on C57BL/6J background (Lefterov et al., 2010). APP/PS1 $\Delta$ E9 mice express mutant familial variants of human amyloid precursor protein (APP) with Swedish mutation (APPsw), and human PS1 (presenilin 1) with deletion in exon 9 (PS1 $\Delta$ E9). $\mathrm{ABCA}^{+/-}$heterozygous mice (DBA/1-Abca $1^{\mathrm{tm} 1 \mathrm{Jdm} / \mathrm{J})}$ were purchased from The Jackson Laboratory on C57BL/6 $\times$ DBA/1 background and crossbred for 10 generations to pure C57BL/6 background in our laboratory. Human ApoE4 (B6.129P2-Apoe $e^{\text {tm 3(APOE } 4) \text { Mae }}$ N8) and ApoE3 (B6.129P2-Apoe tm3(APOE*3)Mae N8) were purchased from Taconic on C57BL/6 background.

Breeding. APP/PS1 $\mathrm{E} 9$ mice were bred to human ApoE4 $4^{+/+}$and ApoE3 ${ }^{+/+}$targeted replacement mice to generate APP/PS1 $\Delta \mathrm{E} 9 /$ ApoE4 ${ }^{+/+}$(referred to as APP/E4) and APP/PS1 $\Delta \mathrm{E} 9 / \mathrm{ApoE}^{+/+}$(referred to as APP/E3) mice expressing only human ApoE isoforms and wild-type Abcal. Separately, Abcal ${ }^{-1-}$ mice were bred to human ApoE4 $4^{+/+}$and ApoE3 ${ }^{+/+}$targeted replacement mice to generate ApoE4 $4^{+/+} / \mathrm{Abcal}^{+/+}(\mathrm{E} 4)$ and ApoE4 ${ }^{+/+} / \mathrm{Abcal}^{-/+}\left(\mathrm{E} 4 / \mathrm{Abcal}^{-1+}\right)$; as well as $\mathrm{ApoE} 3^{+/+} / \mathrm{Abcal}^{+/+}(\mathrm{E} 3)$ and $\mathrm{ApoE} 3^{+/+} / \mathrm{Abcal}^{-1+}(\mathrm{E} 3 /$ $\mathrm{Abca}^{-1+}$ ) (in all these lines, the mouse ApoE is entirely replaced). E4/ $\mathrm{Abca}^{-1+}$ mice were crossbred to APP/E4 to generate APP/PS1 $\Delta \mathrm{E} 9 /$ $\mathrm{ApoE}^{+/+} / \mathrm{Abcal}^{-1+}$ (referred to as APP/E4/Abcal ${ }^{-/+}$). E3/Abca ${ }^{-1+}$ mice were crossbred to APP/E3 to generate APP/PS1 $\Delta$ E9/ApoE3 $3^{+/+}$/ $\mathrm{Abca}^{-1+}$ (referred to as APP/E3/Abca1 ${ }^{-1+}$ ). All mice were littermates and were fed normal mouse chow diet. Male and female mice from each genotype were used for this study. Radial arm water maze tests were performed at 6-8 months or age (mean age, 7.5 months) with mice perfused soon after for evaluation of amyloid phenotype. We used E4, $\mathrm{E} 4 / \mathrm{Abcal}^{-1+}$; as well as E3 and E3/Abca1 ${ }^{-1+}$ as nontransgenic controls for the behavior experiments. Contextual fear conditioning was performed on a separate group of ApoE3 and ApoE4 transgenic mice with an average age of 4.9 months. For microdialysis experiments, we used 4.5month-old APP transgenic mice: APP/E3, APP/E3/Abcal ${ }^{-1+}, \mathrm{APP} / \mathrm{E} 4$, and APP/E4/Abcal ${ }^{-1+}$.

\section{Radial arm water maze}

Two day radial arm water maze (RWM) was used to assess spatial navigational learning as before (Alamed et al., 2006) with minor modifications. The RWM consisted of six arms ( $20 \mathrm{~cm}$ wide, $40 \mathrm{~cm}$ long, $8 \mathrm{~cm}$ high walls above the water) and a central area $(30 \mathrm{~cm}$ in diameter), filled with water (temperature, $21 \pm 1^{\circ} \mathrm{C}$ ) to a level $1 \mathrm{~cm}$ above the hidden platform (10 cm in diameter) (Stoelting). All animals are handled for $2 \mathrm{~min}$ for 2 consecutive days before any behavior testing.

Acquisition phase. We measured the ability of mice to form a representation of the spatial relationship between a safe, but hidden platform and visual cues surrounding the maze. Acquisition testing was performed over 2 consecutive days with mice trained in groups of five or six. Each day, a mouse received two 6 trial blocks and a final 3 trial block (total of 15 trials per day) with a 30 min rest period between blocks. During day 1 of training, a visible platform (flag projecting $6 \mathrm{~cm}$ from the platform) was used during trials $1,3,5,7,9$, and 11 to define the rule of a safe platform. All other trials consisted of animals finding the location of a hidden platform. Animals were allowed $60 \mathrm{~s}$ to find the platform and $20 \mathrm{~s}$ to rest on it. Mice that failed to find the platform were led there by the experimenter and allowed to rest there for $20 \mathrm{~s}$. All animals in a group completed the trial before proceeding, providing a 5 min intertrial interval. The start location was changed for each trial and the platform location was changed between groups.

Open pool task with visible platform. Following acquisition phase, visible platform training was performed to measure swim speed, motivation, and visual acuity. Briefly, all arms were removed from the water maze, distal visual cues were removed from around the maze, and the platform was marked with a flag projecting $6 \mathrm{~cm}$ above the surface of the water. Mice were placed in the maze and allowed $60 \mathrm{~s}$ to locate the platform and $20 \mathrm{~s}$ to rest on it. If they did not find the platform within $60 \mathrm{~s}$, they were led there by the experimenter and remained there for $20 \mathrm{~s}$. Once all animals in a group completed a trial, the position of the platform was moved while the start position remained constant throughout training. Animals were trained in groups of five or six, and training consisted of two 6 trial blocks and a final 3 trial block ( 15 total trials) with a 30 min rest period between blocks.

Performance was recorded with an automated tracking system (AnyMaze; Stoelting) during all phases of training. During the acquisition phase, total number of incorrect arm entries and time errors were combined for the overall performance of an animal during a trial. An incorrect arm entry was defined as the entry of $50 \%$ of the animal's body into an arm that did not contain the hidden platform. A time error was defined as the failure of an animal to enter an arm after 15 s elapsed. For the 15 daily trials, performance during 3 consecutive trials was averaged into a block (total of 5 blocks per day). During the open pool task of training, speed and latency to the platform were used to compare the performance between genotypes.

\section{Contextual fear conditioning}

Contextual fear conditioning (Stoelting) was performed on a separate group of ApoE3 and ApoE4 transgenic mice with an average age of 4.9 months as before (Puzzo et al., 2008; Kornecook et al., 2010) with slight modifications. Briefly, mice were placed in a conditioning chamber for 2 min before the onset of a tone [conditioned stimulus (CS), duration of $30 \mathrm{~s}, 85 \mathrm{~dB}$ sound at $2800 \mathrm{~Hz}$. In the last $2 \mathrm{~s}$ of the CS, mice were given a $2 \mathrm{~s}, 0.7 \mathrm{~mA}$ footshock through the bars on the floor of the chamber, and this cycle was repeated twice. Finally, the mice were allowed to remain in the chamber for $30 \mathrm{~s}$ before being returned to their housing cages. Contextual fear was evaluated $24 \mathrm{~h}$ after training by measuring freezing behavior for $5 \mathrm{~min}$ in the original chamber before mice were returned to their housing cages. Freezing behavior, defined as the absence of movement except for that needed for breathing, was scored using AnyMaze software (Stoelting). Cued fear learning was assessed $24 \mathrm{~h}$ after contextual testing by placing mice in a novel context (gray walls were replaced with black-and-white stripped walls) for $2 \mathrm{~min}$, after which they were exposed to the CS for $3 \mathrm{~min}$, and freezing behavior was measured. All chambers were cleaned between animals with $70 \%$ ethanol. Data are represented as percentage freezing during all stages of testing. 


\section{In vivo microdialysis}

In vivo microdialysis to assess brain interstitial fluid (ISF) $\mathrm{A} \beta 40$ and $\mathrm{A} \beta 42$ in the hippocampus of awake, freely moving mice was performed as previously described (Cirrito et al., 2003; Fitz et al., 2010). Briefly, mice were anesthetized with Avertin (250 mg/kg, i.p.), head shaved, and placed into a stereotaxic frame (Stoelting). A bore hole $(0.75 \mathrm{~mm})$ was made above the left hippocampus (coordinates: $-3.1 \mathrm{~mm}$ from bregma, 2.4 lateral), as well as the right aspect of the skull for placement of an anchoring screw. MD-2250 guide cannulas (Bioanalytical Systems) were stereotactically lowered into the hippocampus $\left(12^{\circ}\right.$ angle, $-0.6 \mathrm{~mm}$ relative to dura mater) and anchored to the bone screw using binary dental cement.

After washing of the MD-2200 microdialysis probes (Bioanalytical Systems) and FEP tubing with $0.15 \%$ BSA in aCSF perfusion buffer (in mM: 1.3 $\mathrm{CaCl}_{2}, 1.2 \mathrm{MgSO}_{4}, 3 \mathrm{KCL}, 0.4 \mathrm{KH}_{2} \mathrm{PO}_{4}, 25 \mathrm{NaHCO}_{3}$, and $122 \mathrm{NaCl}, \mathrm{pH}$ 7.35), the probes were manually inserted through the guide cannula into the hippocampus. To measure $A \beta 40$ and $A \beta 42$, microdialysis probes had a constant flow rate of $1.0 \mu \mathrm{l} / \mathrm{min}$ and samples were collected every $75 \mathrm{~min}$ on ice, $12 \mathrm{~h}$ after probe implantation. To determine ISF A $\beta 40$ and $\mathrm{A} \beta 42 \mathrm{half}-\mathrm{life}, 1 \mathrm{~h}$ baseline samples were taken from hours $12-15$ after probe implantation, and at the beginning of hour 16 , animals were injected with $10 \mathrm{mg} / \mathrm{kg}(a S)-N$ [(1S)-2-[[(7S)-6,7-dihydro-5-methyl-6-oxo-5H-dibenz [b,d]azepin-7-yl] amino]-1-methyl-2-oxoethyl]-3,5-difluoro- $\alpha$-hydroxybenzeneacetamide (LY411575), a $\gamma$-secretase inhibitor (synthesized at Chemical Synthesis Core Facility, Mayo Clinic Jacksonville, Jacksonville, FL), diluted in corn oil. Five additional $75 \mathrm{~min}$ samples were collected for each animal. The levels of A $\beta 40$ and $\mathrm{A} \beta 42$ in each sample were determined by ELISA as described below. At the conclusion of the microdialysis experiment, animals were perfused as described below, and $30 \mu \mathrm{m}$ brain sections were stained with cresyl violet to confirm probe placement.

\section{Animal tissue processing}

Mice were anesthetized with Avertin $(250 \mathrm{mg} / \mathrm{kg}$ of body weight, i.p.) and perfused transcardially (Lefterov et al., 2010). Blood was drawn from the heart before the mice were perfused transcardially with $25 \mathrm{ml}$ of cold 0.1 M PBS, pH 7.4. Brains were rapidly removed and divided into hemispheres, with one of the hemispheres being dissected into the cortex and hippocampus. These parts were snap-frozen on dry ice, while the other hemisphere was drop fixed in $4 \%$ phosphate-buffered paraformaldehyde at $4^{\circ} \mathrm{C}$ for $48 \mathrm{~h}$ before storage in $30 \%$ sucrose.

\section{Histology and immunohistochemistry}

All procedures were as reported previously (Lefterov et al., 2010). Histoprep-embedded hemibrains were cut in the coronal plane at $30 \mu \mathrm{m}$ sections and stored in a glycol-based cryoprotectant at $-20^{\circ} \mathrm{C}$ until staining. Sections were selected $700 \mu \mathrm{m}$ apart, starting from a randomly chosen section $\sim 150 \mu \mathrm{m}$ caudal to the first appearance of the CA3 and dentate gyrus. Sections mounted on slides were washed in PBS for $10 \mathrm{~min}$ and stained with 1,4-bis(3-carboxy-4-hydroxyphenylethenyl)-benzene (X-34) $(100 \mu \mathrm{M})$ for $10 \mathrm{~min}$. Following the staining, sections were washed in water, incubated in $0.2 \% \mathrm{NaOH}$ in $80 \%$ unbuffered ethanol for $2 \mathrm{~min}$, washed again in water, and soaked in PBS for $10 \mathrm{~min}$.

Another set of adjacent sections were immunostained with 6E10 antibody (Koldamova et al., 2005b) (SIG-39340; Covance). Briefly, free-floating sections were blocked for endogenous peroxidases, avidinbiotin quenched, antigen retrieval was performed with $70 \%$ formic acid, and tissue was blocked with $3 \%$ normal goat serum. Sections were then incubated in 6E10 biotin-labeled antibody $(1: 1000)$ at room temperature for $2 \mathrm{~h}$ before being developed with Vectastain ABC Elite kit and a DAB substrate (Vector Laboratories). A final group of adjacent sections were immunostained with polyclonal rabbit anti-GFAP antibody (DK-2600; Dako) for detection of activated microglia as in the study by Lefterov et al. (2009). Briefly, free-floating sections were washed with PBS and blocked with 3\% normal goat serum. Sections were then incubated in anti-GFAP antibody (1:1000) at room temperature for $3 \mathrm{~h}$ before incubation with anti-rabbit 594-labeled secondary antibody (DI-1594; Vector Laboratories) for $1 \mathrm{~h}$ (1:250). Sections were then mounted on slides. Microscopic examination was performed using a Nikon Eclipse 80i microscope (20X magnification). For quantitative analysis, staining in the cortex and hip- pocampus was defined as the percentage area covered by X-34, GFAP, or 6E10 positivity using MetaMorph 7.0 software (Molecular Devices).

\section{Western blotting and ELISA}

The frozen cortices and hippocampi were homogenized separately (Fitz et al., 2010; Lefterov et al., 2010) in tissue homogenization buffer (250 mM sucrose, $20 \mathrm{~mm}$ Tris base, $1 \mathrm{~mm}$ EDTA, $1 \mathrm{~mm}$ EGTA, $1 \mathrm{ml}$ per $100 \mathrm{mg}$ tissue) and protease inhibitors ( $10 \mu \mathrm{g} / \mathrm{ml}$ leupeptin, $10 \mu \mathrm{g} / \mathrm{ml}$ aprotinin, and $10 \mu \mathrm{g} / \mathrm{ml}$ AEBSF [4-(2-aminoethyl)benzenesulfonyl fluoride]) using a glass Dounce. To prepare soluble brain extracts, the initial homogenate was spun at $100,000 \times g$ for $1 \mathrm{~h}$, and the supernatant was used for determination of soluble $\mathrm{A} \beta$ as well as soluble ApoE in the brain. To extract insoluble $\mathrm{A} \beta$, the remaining pellet was resuspended with $70 \%$ formic acid, and samples were sonicated for $30 \mathrm{~s}$, and then spun at $100,000 \times g$ for $1 \mathrm{~h}$ as before (Fitz et al., 2010; Lefterov et al., 2010).

Protein concentration. The Bradford assay was used to determine the protein concentration of all samples. Briefly, diluted sample are mixed 1:1 with $40 \%$ Bradford reagent dye (Bio-Rad) and absorbance at $595 \mathrm{~nm}$ was read on a microplate reader. Concentration is determined by comparison to bovine serum albumin standard curve using linear regression analysis.

A $\beta$ ELISA. A $\beta$ ELISA was performed essentially as in the studies by Fitz et al. (2010) and Lefterov et al. (2010). Briefly, we used 6E10 as the capture antibody (reactive with very high specificity to amino acid residues 1-16 of human $A \beta$ with no cross-reactivity to mouse $A \beta$ ), and anti-A $\beta_{40}(\mathrm{G} 2-10 \mathrm{mAb})$ (specific to amino acids $31-40$ of $\mathrm{A} \beta 40$ and has no cross-reactivity with other $A \beta$ peptides) and anti-A $\beta_{42}(\mathrm{G} 2-13 \mathrm{mAb})$ (specific for $\mathrm{A} \beta 1-42$ and not reactive to $\mathrm{A} \beta 1-38, \mathrm{~A} \beta 1-39$, or $\mathrm{A} \beta 1-40$ but does have $\sim 10 \%$ reactivity to $\mathrm{A} \beta 1-43$ and $\mathrm{A} \beta 1-44$ ) monoclonal antibodies conjugated to horseradish peroxidase (Genetics Company) were used as the detection antibodies. The final values of $A \beta$ were based on $\mathrm{A} \beta 40$ and $\mathrm{A} \beta 42$ peptide standards (Bachem Biosciences) and are normalized to the total protein concentration in the sample, assayed by Bradford assay, and $\mathrm{A} \beta$ values are expressed as picomoles per milligram. $\mathrm{A} \beta$ concentration in ISF and plasma was determined using the same ELISA protocol. With this protocol, our interassay and intraassay CV\% is $<10$, and the standard curve demonstrates good linearity $\left(r^{2} \geq 0.98\right)$ over a wide range of $A \beta$ concentrations from 800 to $6.25 \mathrm{fmol}$. To reduce interassay variation, all samples are run in a single group when possible and read in duplicate.

Western blotting analysis. For Western blotting (WB) analysis, extracts containing 50-100 $\mu \mathrm{g}$ of total protein were mixed with Tris/glycine or NUPAGE denaturing loading buffer, loaded, and electrophoresed on $10 \%$ Tris/glycine gels or NuPAGE Bis-Tris gels (Invitrogen). Gels were transferred to nitrocellulose membranes, incubated with the respective primary antibodies followed by secondary antibodies conjugated to horseradish peroxidase, and processed for visualization by enhanced chemiluminescence Plus-ECL (PerkinElmer). $\beta$-Actin was used as an internal standard. The relative intensities of the bands were quantified by densitometry (ImageQuant, version 5.2; GE Healthcare).

RIPA extraction. To detect Abcal, full-length APP (APPfl) and C-terminal fragments result of $\beta$-secretase cleavages $(\mathrm{CTF} \beta)$ protein extracts were prepared by 1:1 dilution of the initial homogenate with $2 \times$ RIPA buffer in the presence of protease inhibitors, and WBs were performed as before (Koldamova et al., 2005a; Lefterov et al., 2010). Abcal was detected using monoclonal antibody, ab7360 (Abcam), and APPfl and $\operatorname{CTF} \beta$ with $6 \mathrm{E} 10$ antibody. $\beta$-Actin was used as a loading control for all WBs and detected with monoclonal antibody, A5441 (SigmaAldrich). Tau phosphorylation was examined on the RIPA extracts from cortices and hippocampi using PHF phosphospecific monoclonal (pSer202/Thr205) antibody (generously provided by Dr. Peter Davies, Albert Einstein College of Medicine, Bronx, NY). The bands were scanned and normalized to total tau using tau- 5 antibody from Abcam.

ApoE and ApoA-I. ELISA for ApoE was performed on soluble brain extract and plasma samples. We used sandwich ELISA assay with goat anti-human ApoE antibody (AB947; Calbiochem) as the capture antibody and biotin-labeled goat anti-ApoE (K74180B; Meridian Life Sciences) as the detection antibody followed by HRP-labeled streptavidin (Fitzgerald). The ELISA was developed using tetramethylbenzidine (TMB) as substrate (KPL), and the absorbance was read at $650 \mathrm{~nm}$ wave- 
A

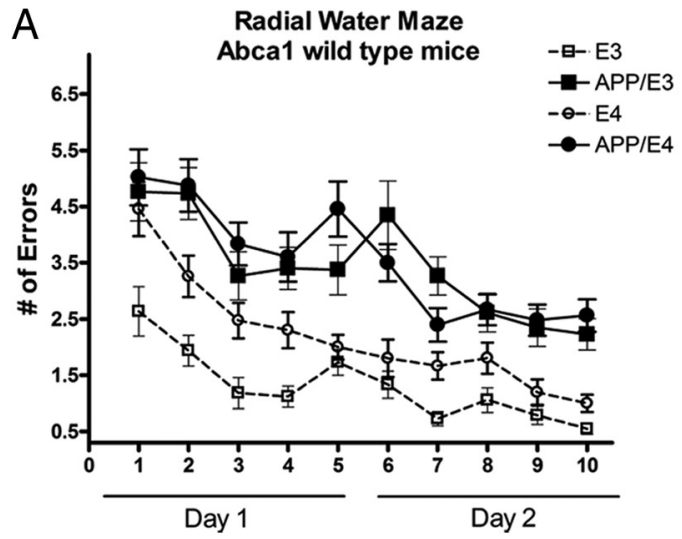

C

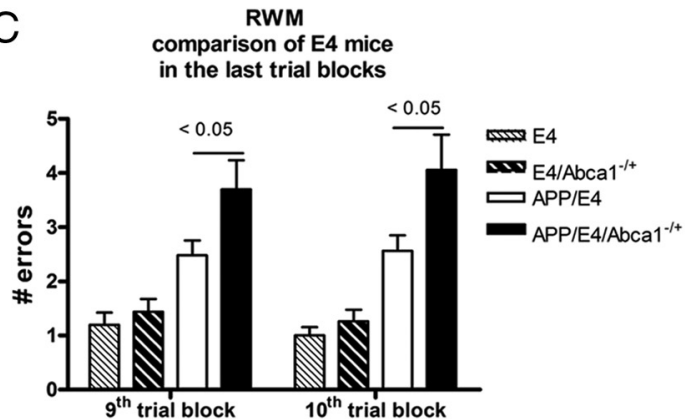

E

Contextual fear conditioning APP mice

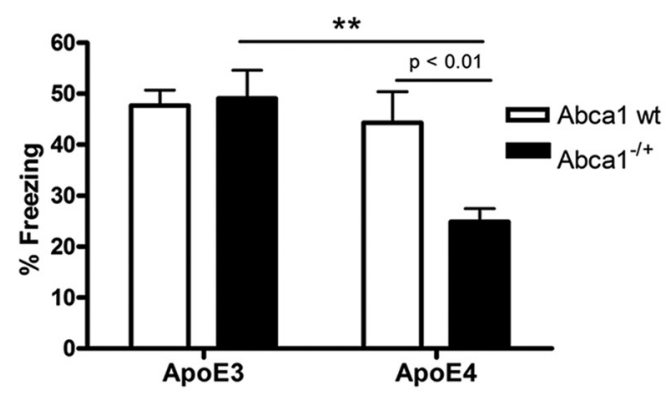

G

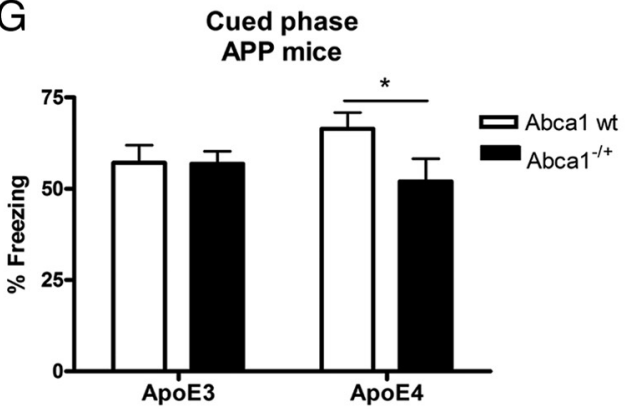

B Radial Water Maze
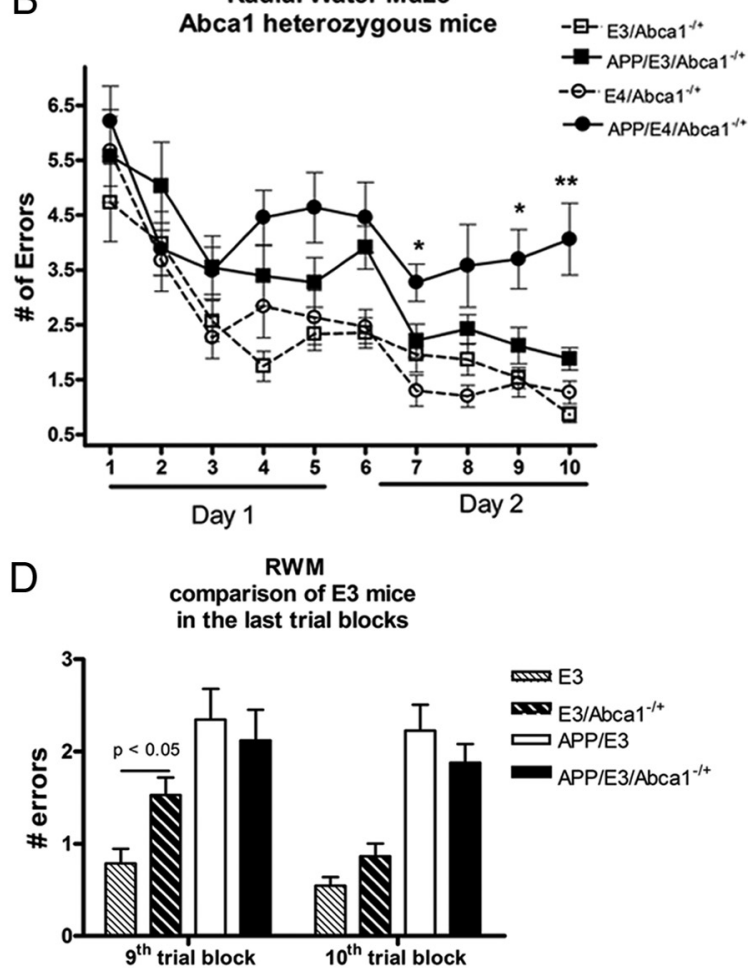

F

Contextual fear conditioning Wild type mice

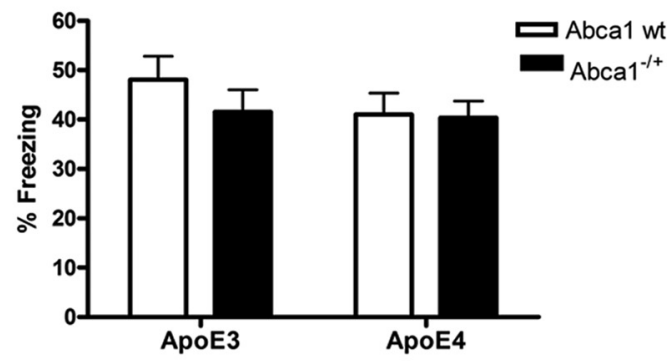

$\mathrm{H}$

Cued phase Wild type mice

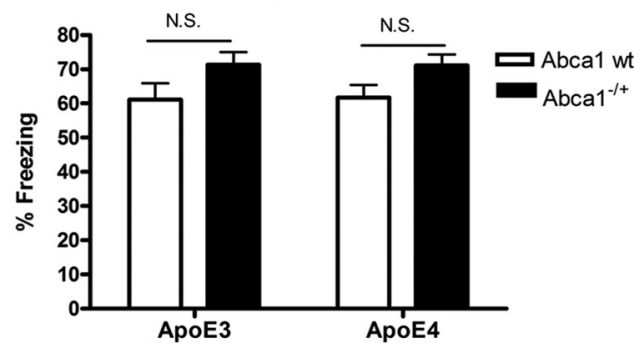

Figure 1. Abca1 gene dose affects cognitive decline in APP/E4 but not in APP/E3 mice. A-D, RWM was used to assess memory deficits in APP/E3 and APP/E4, as well as in APP/E3/Abca 1 -/+ and APP/E4/Abca $1^{-/+}$mice, between 6 and 8 months of age (mean age, 7.5). Nontransgenic E3, E4, E3/Abca $1^{-/+}$, and E4/Abca $1^{-/+}$mice were used as controls. $A$, There was no significant difference in cognitive performance between APP/E3 and APP/E4 mice. Analysis by two-way repeated-measures ANOVA demonstrates a significant effect on genotype ( $p<0.0001)$ but no interaction. There was a significant difference between APP transgenic mice and their respective nontransgenic controls. $N=16-25$ mice per group. $B$, RWM revealed a significant difference in cognitive decline between APP/E3/Abca $1^{-/+}$and APP/E4/Abca $1^{-/+}$mice. Analysis by two-way repeated-measures ANOVA showed an interaction $(p<0.05)$ and significant effect on genotype $(p<0.0001)$. There was a significant difference between APP transgenic mice and their respective nontransgenic controls. ${ }^{*} p<0.05$ and ${ }^{* *} p<0.01$ when APP/E4/Abca $1{ }^{-1+}$ were compared with APP/E3/Abca $1^{-/+}$by $t$ test. $N=10-17$ mice per group. $C$, The graph shows the performance of all ApoE4 mice on the last two trial blocks. $N=10-22$ mice per group. D shows the performance of all ApoE3 mice on the last two trial blocks. $N=11-25$ mice per group. In $\boldsymbol{C}$ and $\boldsymbol{D}$, the two groups were compared by $t$ test. $\boldsymbol{E}, \boldsymbol{F}$, Contextual fear conditioning paradigm was used to assess memory deficits in younger APP/E3, APP/E4, APP/E3/Abca1 ${ }^{-1+}$, and APP/E4/Abca1 ${ }^{-/+}$mice (mean age, 4.9 months). Nontransgenic E3, E4, E3/Abca1 ${ }^{-1+}$, and E4/Abca $1^{-1+}$ age- and gender-matched mice were used as wild-type controls. $E$, Results for APP mice. Analysis by two-way ANOVA revealed an interaction between Abca1 and ApoE genotype $(p<0.05)$ and a main effect of ApoE ( $p<$ 0.01 ) but not of Abca1 genotype $(p=0.06) . p<0.01$, by Bonferroni's posttest; ${ }^{* *} p<0.01$ by $t$ test. $N=7-13$ per group. $\boldsymbol{F}$, Results from contextual fear conditioning (Figure legend continues.) 
A
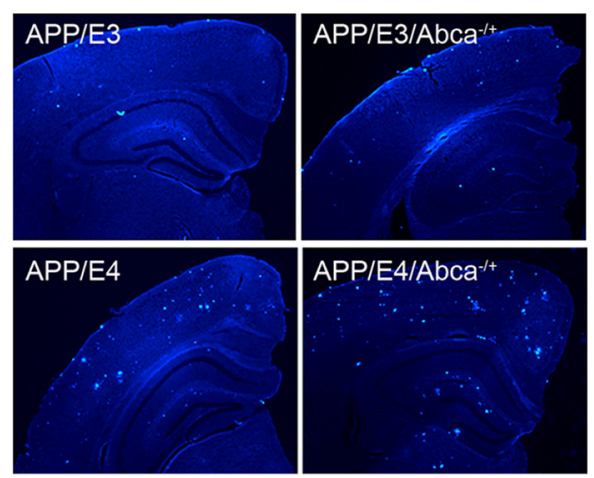

X34 positive plaques

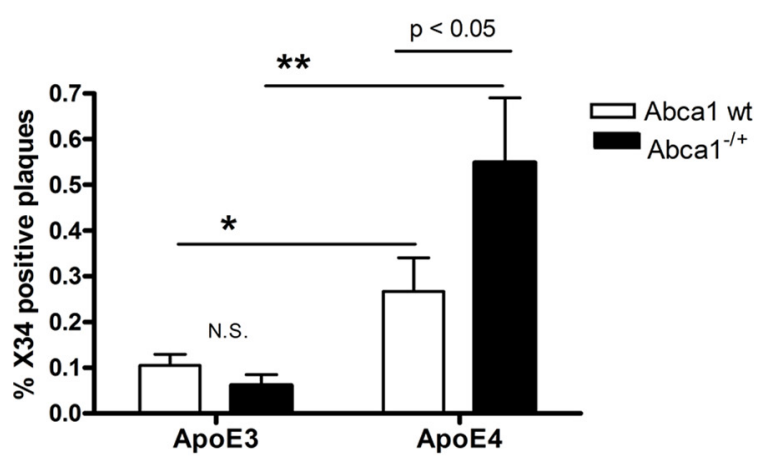

B

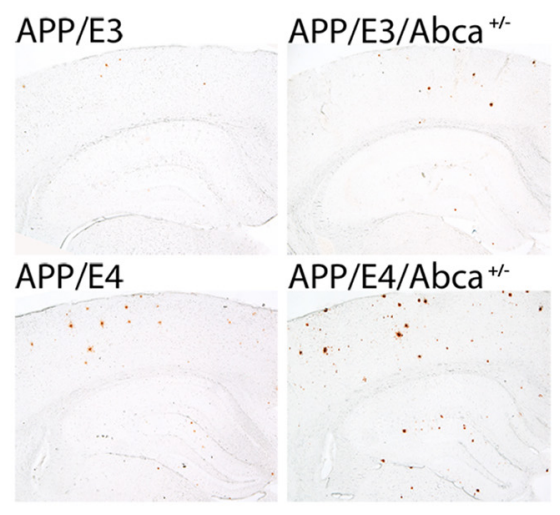

6E10 positive plaques

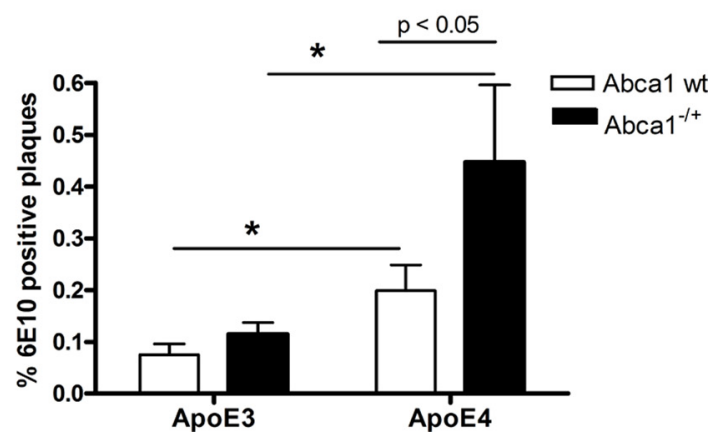

Figure 2. Amyloid plaques are increased by Abca1 hemizygosity in APP/E4 mice but not in APP/E3 mice. Amyloid plaques were compared in APP/E3 and APP/E4 as well as in APP/E3/Abca1 ${ }^{-/+}$ and APP/E4/Abca ${ }^{-1+}$ mice between 6 and 8 months of age (mean age, 7.5).A, Brain sections were stained with X-34 to visualize compact fibrillar amyloid plaques. Representative pictures for X-34 staining are shown above the graphs ( $20 \times$ magnification). X-34-positive amyloid load analyzed by two-way ANOVA and Bonferroni's posttest. There is an interaction between Abca1 and ApoE genotypes $(p<0.05)$ and a significant effect of ApoE genotype $(p<0.001)$, but no effect of Abca1 genotype. Note that the level of compact amyloid plaques in APP/E4/Abca ${ }^{-/+}$is increased by ninefold compared with the level in APP/E3/Abca1 ${ }^{-1+}$ mice (Bonferroni's posttest, $p<0.05$ ). ${ }^{*} p<0.05$ and ${ }^{* *} p<0.01$, two-group comparisons by $t$ test. $N=8-12$ mice per group. $B$, Brain sections were stained with anti-A $\beta$ antibody, $6 \mathrm{E} 10$, to visualize diffuse and compact amyloid plaques. Representative pictures for $6 \mathrm{E} 10$ staining are shown above the graph (20 $\times$ magnification). Analysis is by two-way ANOVA and Bonferroni's posttest. There is no interaction between Abca1 and ApoE genotypes, and there is a significant effect of ApoE $(p<0.01)$, and Abca1 $(p<0.05)$ genotypes; $p<0.05$, by Bonferroni's posttest. Note that APP/E4 have more than twofold increase of plaque load ( ${ }^{*} p<0.05$ by $t$ test), and APP/E4/Abca ${ }^{-1+}$ mice have more than threefold increase in amyloid load versus APP/E3/Abca ${ }^{-1+}\left({ }^{*} p<0.05\right.$ by $t$ test $) . N=8-13$ mice per group. Error bars indicate SEM.

length. To detect ApoA-I, we used solid-phase ELISA assay as before (Koldamova et al., 2001). Briefly, plasma or soluble brain extracts samples were diluted in bicarbonate buffer and loaded directly on polysorb ELISA plate. After overnight incubation, the plate was incubated with blocking solution ( $0.4 \%$ Block Ace; AbD Serotec) for $4 \mathrm{~h}$ at room temperature. As detection antibody we used mouse-specific anti-ApoA-I polyclonal antibody (600-101-196; Rockland) followed by HRP-labeled anti-goat antibody (sc-2020; Santa Cruz Biotechnology). As a substrate, we used TMB, and the absorbance was read at $650 \mathrm{~nm}$ wavelength. As a standard for ApoA-I ELISA, we used recombinant mouse ApoA-I generously provided by Dr. M. Phillips (Children's Hospital of Philadelphia, Philadelphia, PA). Alternatively, ApoA-I level in serum or soluble brain fraction was determined by WB using anti-ApoA-I polyclonal antibody 600-101-196 (see above).

$\leftarrow$

(Figure legend continued.) for wild-type mice. Analysis by two-way ANOVA showed no interaction and no main effects of Abca1 and ApoE. No significant difference between APP mice and their non-APP controls except for APP/E4/Abca ${ }^{-/+}$, which differed significantly from E4/ Abca ${ }^{-1+}$ (APP/E4/Abca ${ }^{-1+}$ percentage freezing, $24.89 \pm 2.56$, vs E4/Abca ${ }^{-1+}$ percentage freezing, $40.31 \pm 3.40 ; p<0.01$ by $t$ test). $N=15-20$ mice per group. $G$, Cued phase of fear conditioning test was performed on the same APP/E3, APP/E4, APP/E3/Abca1 ${ }^{-1+}$, and APP/E4/Abca $1^{-/+}$mice as in $\boldsymbol{E}$. Analysis by two-way ANOVA showed no interaction and no main effects of Abca1 and ApoE. ${ }^{* *} p<0.01$ by $t$ test; $N=7-13$ per group. $H$, Cued phase of fear conditioning test was performed on the same wild-type controls as in $\boldsymbol{F}$. N.S., Not significant. $N=15-20$ mice per group. Error bars indicate SEM.

\section{Total cholesterol}

Aliquots of cleared soluble brain extract were used to determine the total cholesterol levels in the brain using Amplex Red Cholesterol Assay Kit from Invitrogen according to the manufacturer's protocol and as before (Fitz et al., 2010). The fluorescence of the sample was measured in a clear 96-well microplate using a Spectra Max 300 microplate reader (Molecular Devices) with $540 \mathrm{~nm}$ excitation and $590 \mathrm{~nm}$ emission. The cholesterol amount of the sample was determined from a standard curve using GraphPad Prism, version 4.0, and normalized to total protein in the extract.

\section{HDL and LDL concentration}

At time of collection, blood samples were centrifuged at 16,000 rpm for 5 $\mathrm{min}$, and the plasma was collected and snap-frozen on dry ice. Aliquots of $50 \mu \mathrm{l}$ of plasma were assayed for HDL and LDL/very-low-density lipoprotein (VLDL) levels using the Abcam HDL and LDL/VLDL Cholesterol Assay Kit (ab65390) according to the manufacturer's protocol. The OD of the sample was measured in a clear 96-well microplate at $570 \mathrm{~nm}$ wavelength using a Spectra Max 300 microplate reader (Molecular Devices). The cholesterol amount of the sample was determined from a standard curve using GraphPad Prism, version 4.0, and expressed in milligrams per milliliter.

\section{Statistical analysis}

All results are reported as means \pm SEM. Statistical significance of differences between mean scores during acquisition phase of training in the RWM were assessed with two-way repeated-measures ANOVA (general linear model/repeated-measures ANOVA) and Tukey's post hoc analysis 

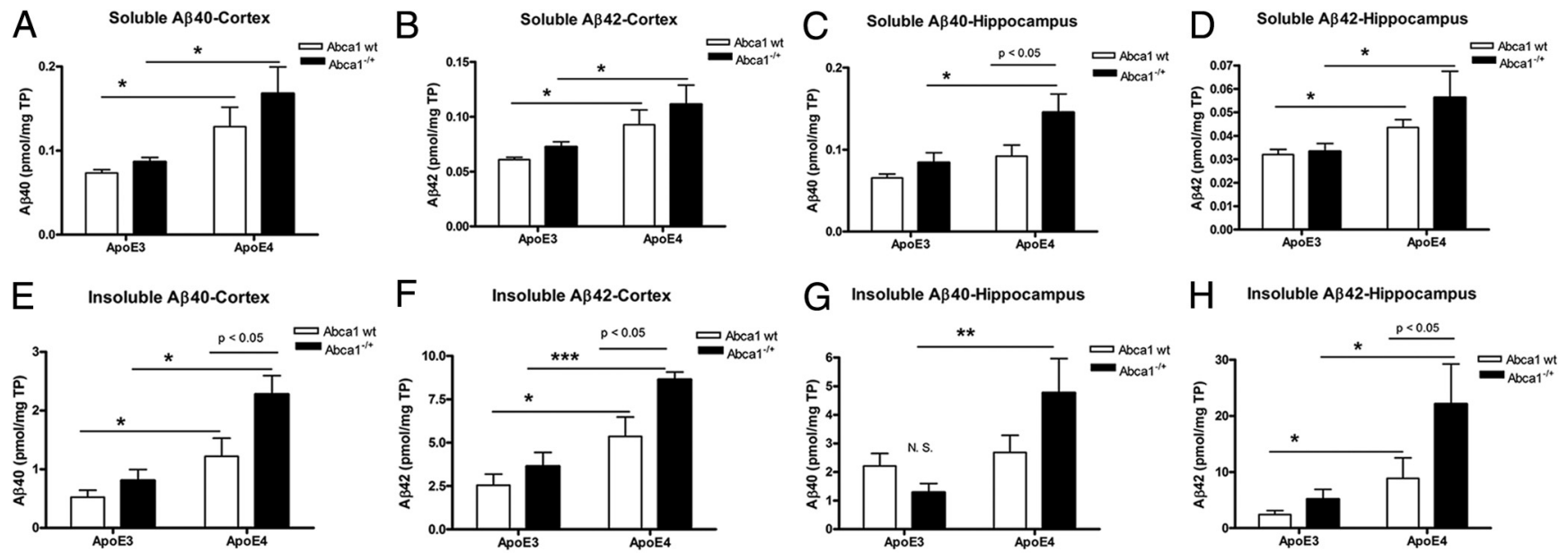

Figure 3. Lack of one Abca1 gene copy increases soluble and insoluble $A \beta$ levels in APP/E4 but not in APP/E3 mice. Soluble proteins were extracted from the cortices $(\boldsymbol{A}, \boldsymbol{B}, \boldsymbol{E}, \boldsymbol{F})$ and hippocampi $(\boldsymbol{C}, \mathbf{D}, \mathbf{G}, \boldsymbol{H})$ of 6- to 8-month-old APP/E3, APP/E4, APP/E3/Abca ${ }^{-1+}$, and APP/E4/Abca $1^{-1+}$ mice. A $\beta 40$ and A $\beta 42$ were measured by ELISA as explained in Materials and Methods. $A$, Soluble $A \beta 40$ in cortex. $N=6-9$ mice per group. $\boldsymbol{B}$, Soluble $A \beta 42$ level in cortex. $N=9-13$ mice per group. For $\boldsymbol{A}$ and $\boldsymbol{B}$, analysis by two-way ANOVA did not show an interaction between $A$ poE and $A b c a 1$. There was a main effect of $\mathrm{ApoE}(p<0.001)$ but not of $\mathrm{Abca} 1 .{ }^{*} p<0.05$ by $t$ test. C, Soluble $\mathrm{A} \beta 40$ level in hippocampus. $N=7-13$ mice per group. Two-way ANOVA: no interaction between ApoE and Abca1, main effect of $A p o E(p<0.001)$ and Abca1 genotypes $(p<0.01) . p<0.05$ by Bonferroni's posttest; ${ }^{*} p<0.5$ by $t$ test. $D$, Soluble $A \beta 42$ level in hippocampus. $N=7-14$ mice per group. Two-way ANOVA: $n$ interaction between ApoE and Abca1, main effect of $\mathrm{ApoE}(p<0.001)$ but not of Abca1. ${ }^{*} p<0.5$ by $t$ test. $E$, Insoluble $A \beta 40$ in cortex. Two-way ANOVA: no interaction between $A p o E$ and $A b c a 1$; main effects of Abca1 $(p<0.01)$ and $A p o E(p<0.0001) . p<0.05$ by Bonferroni's posttest. ${ }^{*} p<0.05$; ${ }^{* *} p<0.01$ by $t$ test. $N=6-14$ mice per group. $F$, Insoluble $\mathrm{A} \beta 42$ in cortex. Two-way ANOVA: no interaction between ApoE and Abca1; main effects of Abca1 $(p<0.05)$ and ApoE $(p<0.001) . p<0.05$ by Bonferroni's posttest. ${ }^{*} p<0.5{ }^{* * *} p<0.001$ by $t$ test. $N=6-14$ mice per group. $G$, Insoluble A $\beta 40$ in hippocampus. Two-way ANOVA: interaction between ApoE and Abca $1(p<0.05)$; main effect of ApoE $(p<0.01)$ but not of Abca1. ${ }^{* *} p<$ 0.01 by $t$ test. $N=7-12$ mice per group. $\boldsymbol{H}$, Insoluble A $\beta 42$ in hippocampus. Two-way ANOVA: no interaction between ApoE and Abca1; main effects of Abca1 ( $p<0.05)$ and ApoE $(p<0.001)$. $p<0.05$ by Bonferroni's posttest. ${ }^{*} p<0.05$, by $t$ test. $N=6-14$ mice per group. Error bars indicate SEM.

for multiple comparisons using Genotype and Trial Block Number as sources of variation. The rest of the data (contextual fear conditioning, immunohistochemistry, ELISA, etc.) were analyzed by two-way ANOVA followed by Bonferroni's post hoc test with Abcal status and ApoE isoform as sources of variation. Additional comparisons between two groups were made by $t$ test. A $\beta$ half-life was determined by nonlinear regression analysis using an equation of one-phase exponential decay $\left[Y=\operatorname{span}^{\star} \exp \left(-K^{\star} X\right)+\right.$ plateau with a rate constant $K$; the half-life is $0.69 / K]$. Correlation was assessed using nonparametric analysis to determine Spearman's rank coefficient $(\rho)$. All statistical analyses were performed in GraphPad Prism, version 4.0, or SPSS, version 19, IBM, and differences were considered significant where $p<0.05$.

\section{Results}

\section{Abcal effect on cognitive performance depends on human} ApoE isoform

To examine the effects of Abcal on AD-like phenotype, we used $\mathrm{APP} / \mathrm{PS} 1 \Delta \mathrm{E} 9$ mice expressing human ApoE3 (referred to as APP/ E3) and ApoE4 (APP/E4) isoforms. First, we determined cognitive deficits in mice aged 7.5 months using the RWM paradigm. As shown in Figure $1 \mathrm{~A}$, among mice expressing wild-type Abcal there was a significant difference between APP transgenic mice and their respective nontransgenic controls (compare APP/E3 to E3 mice and APP/E4 to E4 mice). However, we did not find a statistical difference between APP/E3 and APP/E4 mice. Next, we crossed APP/E3 and APP/E4 mice to Abca1 knock-out mice to generate mice lacking one copy of Abcal, namely APP/E3/ $\mathrm{Abcal}^{-1+}$ and APP/E4/Abcal ${ }^{-1+}$ mice. As seen in Figure $1 B$, $\mathrm{APP} / \mathrm{E} 4 / \mathrm{Abcal}^{-/+}$mice performed significantly worse than APP/E3/Abcal ${ }^{-/+}$particularly during the last trial blocks $(~ p<$ 0.05 for trial blocks 10,9 , and 7). This result suggests that the lack of one copy of Abcal significantly impairs the ability of APP/E4 mice to acquire spatial memory. We also directly compared the performance of all ApoE4 and all ApoE3 mice in the last two trial blocks and found that Abcal deficiency significantly aggravated memory deficits in APP/E4/Abcal ${ }^{-1+}$ (Fig. 1C) but not in APP/
E3/Abcal ${ }^{-/+}$mice (Fig. $1 D$ ). The differences in behavior could not be attributed to swim speed or motivation as there was no significant difference between genotypes in performance during the open pool visual platform testing (data not shown).

Memory deficits in mice of the same genotypes were also examined at an earlier age (mean age, 4.9 months) using a contextual fear conditioning paradigm (Kornecook et al., 2010). We specifically chose younger mice, which are at the onset of amyloid pathology and only rarely have amyloid plaques. The results for APP-expressing mice are shown in Figure $1 E$ and for wild-type controls in Figure $1 F$. As visible from Figure $1 E$, there is no difference between APP/E3, $\mathrm{APP} / \mathrm{E} 4$, and $\mathrm{APP} / \mathrm{E} 3 / \mathrm{Abcal}^{-/+}$mice. Furthermore, these mice did not differ from their nontransgenic controls (compare the results for APP mice shown in Fig. $1 E$ with the results for wild mice in Fig. $1 F$ ). This suggests that amyloid pathology particularly in APP/E3, APP/ $\mathrm{E} 4$, and APP/E3/Abcal ${ }^{-1+}$ is not fully advanced to cause memory deficits. However, APP/E4/Abca1 ${ }^{-1+}$ mice differed significantly from APPE4 and APP/E3/Abcal ${ }^{-/+}$mice. APP/E4/Abcal ${ }^{-/+}$mice also differed significantly from their nontransgenic controls (APP/ $\mathrm{E} 4 / \mathrm{Abca}^{-/+}$percentage freezing, $24.89 \pm 2.56$, vs E4/Abcal ${ }^{-/+}$ percentage freezing, $40.31 \pm 3.40 ; p<0.01)$. The results from cued phase of this test are shown in Figure 1, $G$ and $H$; APP/E4/Abca $1^{-/+}$ were significantly impaired compared with APP/E4 mice. The conclusion from this study is that Abcal deficiency accelerates the appearance of memory deficits in APP/E4 mice but not in APP/E3 mice.

Overall, the results from the behavior experiments suggest that, in terms of cognition, APP/E4 mice are more vulnerable to Abcal deficiency than APP/E3 mice.

\section{Amyloid load is increased by Abca1 hemizygosity in APP/E4 mice but not in APP/E3 mice}

To visualize compact fibrillar amyloid plaques, brain sections were stained with X-34, and the results are presented in Figure $2 \mathrm{~A}$. Analysis by two-way ANOVA demonstrated that there is an 
A Brain cholesterol level
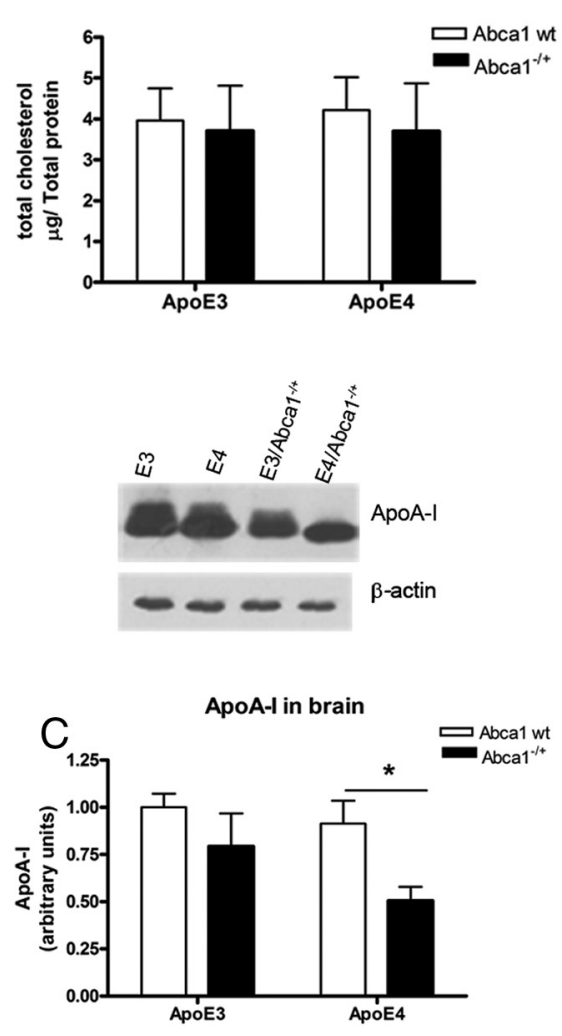

B

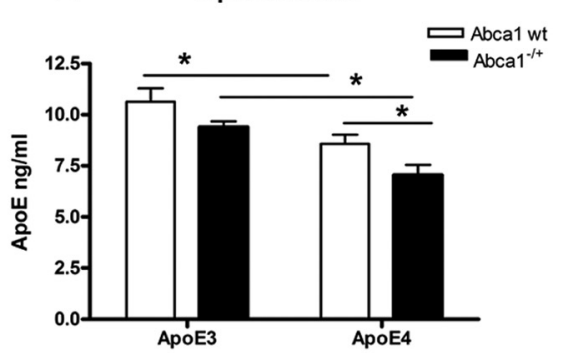

D
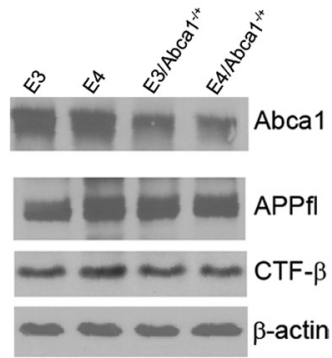

E

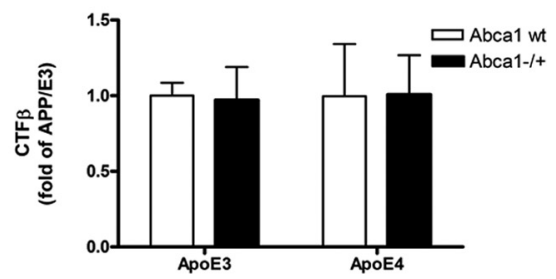

Figure 4. ApoE and ApoA-l levels in soluble brain fraction are decreased in APP/E4/Abca ${ }^{-/+}$but not in APP/E3/Abca $1^{-/+}$ mice. Soluble brain exacts were used from the cortices and hippocampi of 6- to 8-month-old APP/E3, APP/E4, APP/E3/Abca1 ${ }^{-1+}$ and APP/E4/Abca $1^{-/+}$mice. $A$, Cholesterol concentration was measured in the soluble brain fraction as explained in the text. Two-way ANOVA demonstrated no interaction and no effects of genotypes. $N=6-9$ mice per group. $\boldsymbol{B}$, ApoE was detected in the soluble fraction of cortex and hippocampus by ELISA as explained in Materials and Methods. Analysis is by two-way ANOVA. There is no interaction between $A p o E$ and Abca1; there are main effects of $A b c a 1(p<0.01)$ and $A p o E(p<0.001) .{ }^{*} p<0.5$ by $t$ test. $N=6-10$ mice per group. C, ApoA-I was detected in the soluble fraction of cortex and hippocampus by WB. The intensity of the bands were quantified and analyzed by two-way ANOVA. There is no interaction between ApoE and Abca1, and there is a main effect of $A b c a 1(p<0.05)$ but not of $A p o E$. ${ }^{*} p<0.5$ by $t$ test. $N=6-8$ mice per group. $D$, Western blotting for $A b c a 1$, full-length APP (APPfl), and C-terminal fragments result of $\beta$-secretase cleavage (CTF $\beta$ ). $\beta$-Actin is shown as a loading control. $\boldsymbol{E}$ represents the quantification of $\operatorname{CTF} \beta$. Note that there is no difference between the genotypes. $N=6-8$ mice per group. Error bars indicate SEM.

interaction between Abcal and ApoE genotypes $(p<0.05)$. As visible in Figure $2 A$, there was no significant difference between amyloid plaque levels in APP/E3 and APP/E3/Abcal ${ }^{-/+}$, while there was more than twofold increase when APP/E4 were compared with APP/E4/Abcal ${ }^{-1+}$ (posttest, $p<0.05$ ). Remarkably, the compact amyloid plaques in APP/E4/Abca ${ }^{-1+}$ compared with APP/E3/Abca1 ${ }^{-/+}$mice were increased ninefold.

To visualize all, including diffuse and compact amyloid plaques, brain sections were stained with $6 \mathrm{E} 10$ anti-A $\beta$ antibody (Fig. 2 B). Analysis by two-way ANOVA showed that there was no interaction between Abcal and ApoE genotypes, but there were significant main effects of ApoE $(p<0.01)$ and Abcal $(p<0.05)$ genotypes. Similarly to X-34 results, we found a significant difference between APP/E4 and APP/E4/Abca ${ }^{-/+}$mice (Bonferroni's posttest, $p<0.05$ ), but no significant difference between $\mathrm{APP} / \mathrm{E} 3$ and APP/E3/Abca $1^{-1+}$ mice. Furthermore, as visible in Figure $2 B, \mathrm{APP} / \mathrm{E} 4 / \mathrm{Abca} 1^{-/+}$mice had threefold more amyloid load over APP/E3/Abcal ${ }^{-/+}$mice, which was statistically significant. These results demonstrate that Abcal deficiency exacerbates amyloid phenotype in mice expressing human ApoE4 mice but not in mice expressing human ApoE3.
Soluble $A \boldsymbol{\beta}$ level is increased in the brain of APP/E4 and APP/E4/Abca1 ${ }^{-/+}$mice

Next, we compared the level of soluble A $\beta$ in the brains. Soluble $A \beta$ was extracted separately from cortices and hippocampi, followed by extraction of the insoluble $\mathrm{A} \beta$. $\mathrm{A} \beta$ level was measured by ELISA; the results for cortex are shown in Figure $3, A$ and $B$, and for hippocampus in Figure 3, $C$ and $D$. Analysis by two-way ANOVA did not show an interaction between ApoE and Abcal genotypes, and there was a main effect of ApoE $(p<0.001)$ but not of Abcal genotype. We found a significant difference in $\mathrm{A} \beta 40$ and $\mathrm{A} \beta 42$ levels in the cortex (Fig. $3 A, B$ ), and in $\mathrm{A} \beta 42$ level in the hippocampus of APP/E4 mice (Fig. 3D) compared with APP/E3 mice confirming previous studies (Bales et al., 2009; Castellano et al., 2011). There was a significant difference between soluble $A \beta 40$ and $A \beta 42$ levels in the cortex and hippocampus of APP/E4/ Abca ${ }^{-/+}$when compared directly with $\mathrm{APP} / \mathrm{E} 3 / \mathrm{Abca}^{-/+}$mice (Fig. 3A-D; $p<0.5$ by $t$ test).

Abcal deficiency increases insoluble A $\beta$ level in APP/E4 but not in APP/E3 mice Next, we compared the level of insoluble $\mathrm{A} \beta$ in the cortex and hippocampus. As shown in Figure $3, E$ and $F$, insoluble $A \beta 40$ and $A \beta 42$ levels in the cortex of $\mathrm{APP} / \mathrm{E} 4 / \mathrm{Abca}^{-/+}$mice were increased more than twofold compared with APP/ E3/Abca1 ${ }^{-1+}$ mice. For Figure 3, E and $F$, analysis by two-way ANOVA demonstrated no interaction between Abcal and ApoE, but there were significant main effects of both genotypes. Importantly, there was a significant difference between A $\beta 40$ level in APP/E4 and APP/E4/Abca $1^{-1+}$ mice (posttest, $p<0.05$ ) but not between APP/E3 and APP/E3/ Abca $1^{-1+}$ mice.

Figure $3 G$ demonstrates that insoluble $\mathrm{A} \beta 40$ in the hippocampus of $\mathrm{APP} / \mathrm{E} 4 / \mathrm{Abcal}^{-/+}$mice was increased more than threefold compared with APP/E3/Abca ${ }^{-1+}$ mice $(p<$ $0.05)$, but there was no difference when these mice were compared with APP/E4. Furthermore, analysis for A $\beta 40$ showed that there was an interaction between Abcal and ApoE genotypes. Finally, as seen in Figure $3 H$, insoluble $A \beta 42$ in the hippocampus of APP/E4/Abca $1^{-/+}$was significantly different from $\mathrm{A} \beta 42$ level of APP/E4 (posttest, $p<0.05$ ). Similarly, insoluble $\mathrm{A} \beta 42$ in the hippocampus of $\mathrm{APP} / \mathrm{E} 4 / \mathrm{Abca} 1^{-/+}$ mice was increased more than fourfold compared with APP/ E3/Abcal ${ }^{-1+}$ mice. Two-way ANOVA for A $\beta 42$ demonstrated no interaction between Abcal and ApoE but significant main effects of both genotypes. The conclusion from these experiments is that the deficiency of Abcal significantly increases insoluble $\mathrm{A} \beta$ level in APP/E4 mice but not in APP/E3 confirming the immunohistochemistry results (Fig. 2). 
Soluble ApoE and ApoA-I levels are decreased in the brain of APP/E4/Abca $1^{-1+}$ mice

Next, we examined the levels of total cholesterol and apolipoproteins in the soluble brain fraction. There was no difference in cholesterol concentration between mice of any genotype, confirming previous results that Abcal deficiency does not affect brain cholesterol level (Wahrle et al., 2004). For ApoE level (Fig. 4B), analysis by two-way ANOVA demonstrated no interaction between ApoE and Abcal genotypes, but there were significant main effects of Abcal $(p<0.01)$ and ApoE $(p<0.001)$ genotypes. Furthermore, there was a statistical significance when $\mathrm{APP} / \mathrm{E} 3$ were compared with $\mathrm{APP} / \mathrm{E} 4$ mice, confirming previous report (Bales et al., 2009), as well as between APP/E3/ Abcal $^{-1+}$ and APP/E4/Abcal ${ }^{-1+}$ mice. Finally, Abcal deficiency caused a differential decrease of ApoE level in APP/E4 (compare APP/E4 with APP/E4/Abcal ${ }^{-/+}, p<$ $0.05)$, but not in APP/E3 mice. As visible from Figure $4 C$, ApoA-I level was not significantly different between APP/E3 and APP/E4 mice. Analysis by two-way ANOVA demonstrated that there is a main effect of Abcal $(p<0.05)$ but not of ApoE genotype, which was anticipated. Furthermore, the result in Figure $4 C$ demonstrates that there is a significant difference between ApoA-I level of $\mathrm{APP} / \mathrm{E} 4$ and $\mathrm{APP} / \mathrm{E} 4 / \mathrm{Abca}{ }^{-1+}$ mice $(p<0.05)$. To examine whether there was an effect on APP processing, we measured $\mathrm{CTF}-\beta$, a result of $\beta$-secretase cleavage of APP, and did not find a difference between the genotypes (Fig. 4, see the graph in $E$ and the picture shown in $D$ ). This result confirms previous studies that demonstrated neither Abcal nor ApoE isoform affect APP processing (Koldamova et al., 2005b; Castellano et al., 2011).

\section{$\mathrm{A} \boldsymbol{\beta}$ clearance from $\mathrm{CNS}$ is delayed in APP/E4 mice and worsens by Abcal deficiency}

To examine $\mathrm{A} \beta$ level in ISF, we performed in vivo microdialysis in freely moving mice (Fig. $5 A, B$ ). For $\mathrm{A} \beta 40$ and $\mathrm{A} \beta 42$, there was no interaction between Abcal and ApoE, but there were significant main effects of both genotypes. Most importantly, Abcal deficiency caused statistically significant increase of ISF A $\beta$ level in APP/E4/Abcal ${ }^{-/+}$mice compared with APP/E4 (Fig. $5 A, B$; $p<0.001$ by posttest). In contrast, there was no difference in ISF $\mathrm{A} \beta$ concentration between APP/E3 and APP/E3/Abca ${ }^{-/+}$mice. As visible from Figure 5, $A$ and $B, A \beta 40$ level in ISF was increased twofold and $\mathrm{A} \beta 42$ was increased threefold when ApoE3expressing mice were compared with their respective ApoE4 counterparts (compare APP/E3/Abcal ${ }^{-/+}$with APP/E4/ $\mathrm{Abca}^{-1+}$, and APP/E3 with APP/E4).

To measure the time of $A \beta$ elimination from the brain, we used a $\gamma$-secretase inhibitor to block the production of $A \beta$ (Fig. $5 C, D)$ (Cirrito et al., 2003). In general, the results shown in Figure $5, C$ and $D$, demonstrate that $\mathrm{A} \beta 40$ and $\mathrm{A} \beta 42$ half-lives are increased in APP/E4 and APP/E4/Abca ${ }^{-1+}$ mice versus their respective ApoE3 isoforms. When we compared APP/E4 with APP/ group. Error bars indicate SEM.
B AB42 level in ISF

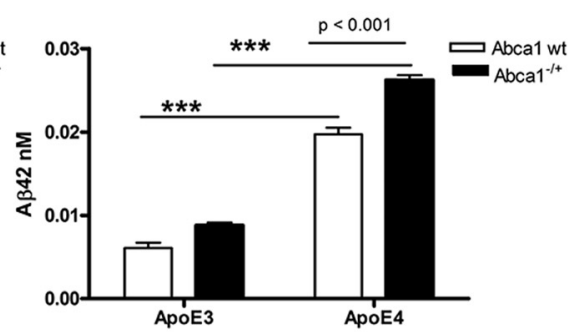

D A 442 Half-life

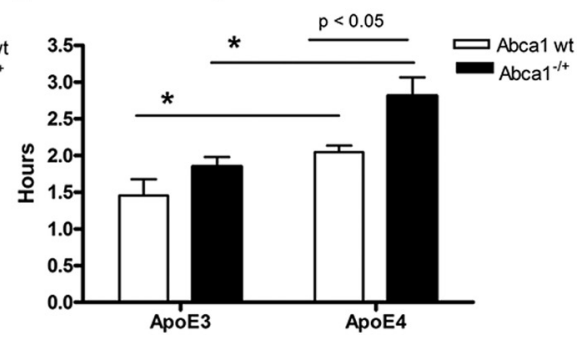

Figure 5. $A \beta$ clearance from the brain is decreased in APP/E4 and APP/E4/Abca $1^{-1+}$ mice. In vivo microdialysis was per作 $\gamma$-secretase inhibitor LY411575 $(10 \mathrm{mg} / \mathrm{kg})$. A $\beta$ half-life was calculated by nonlinear regression analysis (one-phase exponential . D, A 342 half-life is increased in APP/E4 and APP/E4/Abca1 ${ }^{-1+}$ mice. There is no interaction between ApoE and Abca1; main effects of $\mathrm{ApoE}(p<0.01)$ and $\mathrm{Abca} 1(p<0.01) . p<0.05$ by Bonferroni's posttest; ${ }^{*} p<0.05$ by $t$ test. $N=4-5$ mice per

E4/Abcal ${ }^{-1+}$ mice, $\mathrm{A} \beta 40$ clearance showed a trend toward decrease, but the difference was insignificant (Fig. 5C). Two-way ANOVA analysis demonstrated effect only of ApoE but not of Abcal genotype. In contrast, $\mathrm{A} \beta 42$ half-life was significantly affected by ApoE $(p<0.01)$ and Abcal $(p<0.01)$ genotypes. We also found that $\mathrm{A} \beta 42$ clearance was significantly decreased in APP/E4/Abcal ${ }^{-1+}$ mice versus APP/E4 (Fig. 5D; $p<0.05$ by Bonferroni). Importantly, the lack of one copy of Abcal did not affect $\mathrm{A} \beta 40$ and $\mathrm{A} \beta 42$ half-lives in $\mathrm{APP} / \mathrm{E} 3$ mice. The conclusion from these studies is that ApoE4 delays the clearance of $A \beta$ from the brain and Abcal deficiency exacerbates this effect.

\section{Plasma levels of $\mathrm{A} \beta 42$ and $\mathrm{HDL}$ are decreased in APP/E4 and} APP/E4/Abca $1^{-/+}$mice

Next, we compared $\mathrm{A} \beta$ levels in the plasma of $\mathrm{APP} / \mathrm{E} 3, \mathrm{APP} / \mathrm{E} 4$, $\mathrm{APP} / \mathrm{E} 3 / \mathrm{Abcal}^{-1+}$, and APP/E4/Abcal ${ }^{-1+}$ mice. We reasoned that, if human ApoE isoforms differentially affect $\mathrm{A} \beta$ clearance from the brain, this will reflect on peripheral $A \beta$ concentration. Figure 6, $A$ and $B$, shows that APP/E3/Abcal ${ }^{-1+}$ mice had $50 \%$ more A $\beta 40$ in plasma, and $30 \%$ more $\mathrm{A} \beta 42$ than APP/E4/ Abca $1^{-/+}$mice. However, we did not find a difference between $\mathrm{A} \beta 40$ and $\mathrm{A} \beta 42$ level when APP/E4 mice were compared with $\mathrm{APP} / \mathrm{E} 4 / \mathrm{Abca}^{-/+}$. Importantly, the results from two-way ANOVA demonstrated that there is a significant main effect of Abcal on $\mathrm{A} \beta 42$ level in plasma but not on $\mathrm{A} \beta 40$.

We also measured ApoE and ApoA-I levels in plasma. For ApoE, two-way ANOVA showed a main effect of ApoE but not of Abcal genotype (Fig. 6C). Furthermore, APP/E4/Abca ${ }^{-1+}$ mice 
A
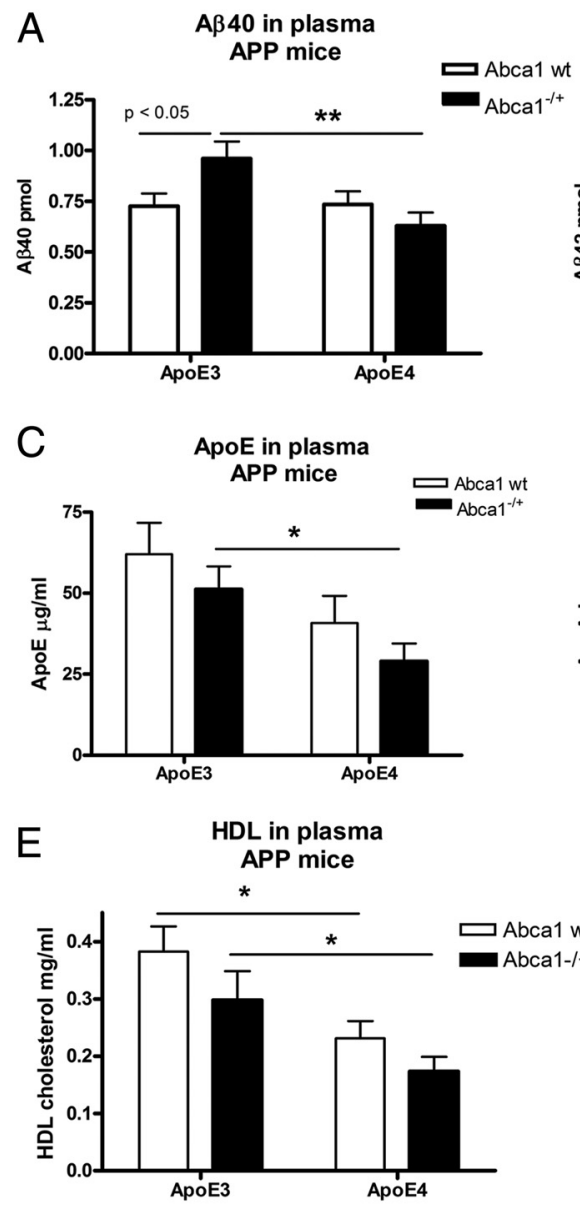

(Fig. 6E, compare APP/E3 with APP/E4 and $\mathrm{APP} / \mathrm{E} 3 / \mathrm{Abcal}^{-/+}$with APP/E4/Abcal ${ }^{-/+}$). Abcal deficiency caused a trend toward decreased HDL level in both APP/E3 and APP/E4 mice, but the difference was not statistically significant due to the variability between mice. We measured LDLs, and the results presented in Figure $6 F$ show that there was no statistical difference between genotypes.

Higher plasma HDL level correlates to a lower amyloid load in the brain

To assess the relationship between plasma HDL and X-34-positive plaques in the brain, we performed a correlation analysis. Figure $7 A$ shows that there is a negative correlation between the two variables $(p<0.01)$. This result demonstrates that mice with a higher level of HDL in the plasma display less amyloid plaques in their brains. In contrast, we did not find a correlation between ApoE level in brain or plasma and X-34positive plaques (data not shown). Furthermore, as seen in Figure $7 B$, there is a negative correlation between $A \beta 42$ level in plasma and X-34-positive plaques. In contrast, we did not find a correlation between $A \beta 40$ level in plasma and X-34 plaques (data not shown). Finally, we examined the relationship between the levels of HDL and $A \beta 42$ in plasma. As visible from Figure $7 C$, there was a positive correlation between HDL and A $\beta 42(p<0.01)$. Similar positive correlation was found between ApoE concentration and $\mathrm{A} \beta 42$ in plasma $(\rho=0.37$, $p<0.05$; data not shown). These experiments suggest that ApoE and HDL in periphery may have a role in $\mathrm{A} \beta$ clearance from the brain.

\section{Discussion}

In this study, we examined Abcal gene dose effect on the phenotype of APP transgenic mice expressing human ApoE3 or ApoE4 isoforms. Surprisingly, our results demonstrate that the lack of one copy of Abcal significantly aggravates

had a statistically significant decrease of ApoE level compared with APP/E3/Abcal ${ }^{-1+}$ mice. Previously, we and others have shown that ApoA-I and HDLs are important for $\mathrm{A} \beta$ aggregation and cognitive decline in experimental mice (Lefterov et al., 2010; Lewis et al., 2010). Interestingly, Abcal genotype had a significant main effect on ApoA-I levels and its deficiency affected significantly ApoA-I concentration in APP/E4 mice (Fig. 6D, compare $\mathrm{APP} / \mathrm{E} 4$ with APP/E4/Abcal ${ }^{-/+}$). There was a trend toward decrease of ApoA-I in APP/E3/Abca1 ${ }^{-/+}$, but the difference was insignificant.

Next, we measured the level of HDL in the plasma of all four genotypes. The results presented in Figure $6 E$ demonstrate a statistically significant difference between ApoE3 and ApoE4 genotypes, which was apparent in mice expressing one or two copies of Abcal memory deficits and amyloid pathology in APP/E4 but not in APP/E3 mice. An important finding of the study was that $A \beta$ clearance from the brain was decreased by $A b c a 1$ deficiency in APP/E4/Abcal ${ }^{-/+}$but not in APP/E3/Abcal ${ }^{-/+}$mice. In contrast, Abcal deficiency did not affect cognition, amyloid phenotype, and $\mathrm{A} \beta$ clearance in APP mice expressing ApoE3. Interestingly, the correlation between plasma HDL and brain amyloid load (Fig. 7) suggests that there may be a causative connection between peripheral lipoproteins and $\mathrm{A} \beta$ load in the CNS.

Previous studies demonstrated that ABCA1 affects amyloid deposition and memory deficits in experimental animals (Hirsch-Reinshagen et al., 2005; Koldamova et al., 2005b; Wahrle et al., 2005; Lefterov et al., 2009). Furthermore, treatment with 

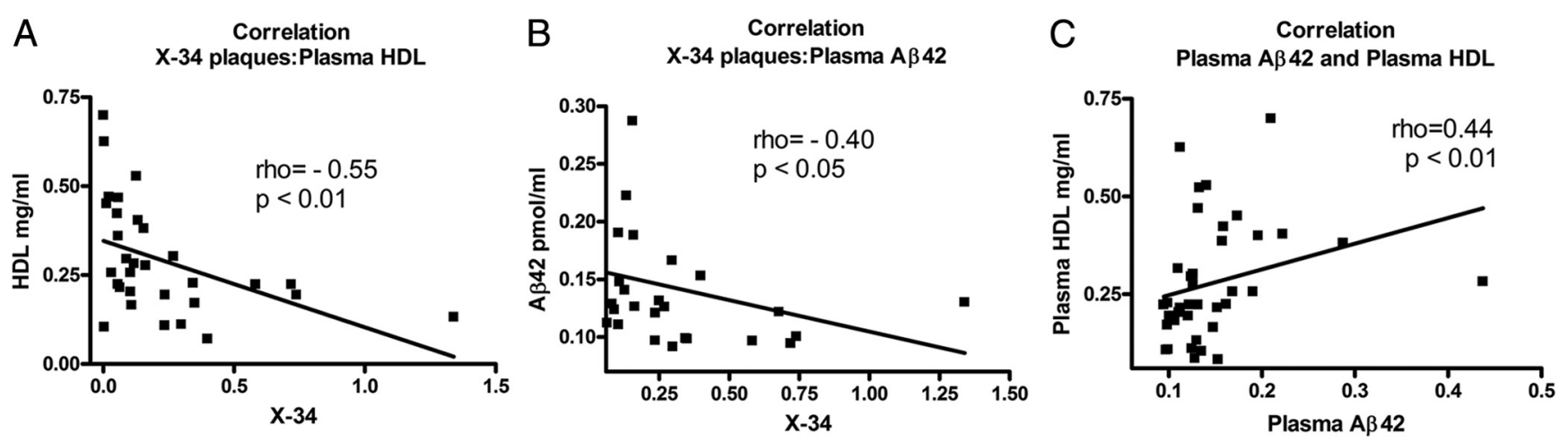

Figure 7. HDL level in plasma negatively correlates to amyloid plaques in the brain. For $\boldsymbol{A}-\boldsymbol{C}$, Spearman's correlation analysis was performed on groups of APP/E3, APP/E3/Abca1 ${ }^{-/+}$, APP/E4, and APP/E4/Abca1 ${ }^{-1+}$ mice. $\boldsymbol{A}$, There is a negative correlation between plasma HDL and X-34-positive amyloid plaques in the brain. $\rho=-0.55 ; p<0.01 ; N=31 . \boldsymbol{B}$, There is a negative correlation between X-34-positive amyloid plaques in brain and A $\beta 42$ level in plasma. $\rho=-0.40 ; p<0.05 ; N=38$. $C$, There is a positive correlation between plasma levels of $A \beta 42$ and $H D L$. $\rho=0.44 ; p<0.01 ; N=39$.

LXR and RXR ligands, which increases Abca1 expression significantly, ameliorates amyloid pathology and improves cognitive function (Koldamova et al., 2005a; Jiang et al., 2008; Donkin et al., 2010; Fitz et al., 2010; Cramer et al., 2012). Last, transgenic mice overexpressing Abcal in brain have less amyloid plaques (Wahrle et al., 2008). There are several genome-wide association studies that reported a genetic link between single-nucleotide polymorphisms spanning $\mathrm{ABCA} 1$ and late-onset $\mathrm{AD}$ (Wollmer et al., 2003; Katzov et al., 2004; Sundar et al., 2007; Reynolds et al., 2009). However, other studies did not replicate the published association ( $\mathrm{Li}$ et al., 2004; Shibata et al., 2006; Wahrle et al., 2007) and some did observe a possible interaction between ABCA1 and APOE in Hispanics (Shibata et al., 2006). The effect of $A B C A 1$ is attributed to its role in modifying the lipidation and stability of ApoE and ApoA-I, and one consequence of its deficiency is the decreased level of these apolipoproteins in the brain (Hirsch-Reinshagen et al., 2005; Koldamova et al., 2005b; Wahrle et al., 2005; Lefterov et al., 2009). It is speculated that the lack of Abcal can affect A $\beta$ aggregation or clearance. Previously, we reported that APP23 mice lacking one copy of Abcal experienced memory deficits in correlation to the increased level of soluble $\mathrm{A} \beta$ oligomers (Lefterov et al., 2009). Here, we show that the level of ApoE and ApoA-I in the brain is significantly affected by Abcal deficiency only in APP/E4 mice but not in APP/E3 mice (Fig. $4 B, C)$, thus supporting this hypothesis. Furthermore, the decreased level or lipidation of ApoE as a result of Abcal deficiency can affect $\mathrm{A} \beta$ clearance, which is apparent in APP/E4 but not APP/E3 mice (Fig. 5).

The exact mechanism by which $A P O E$ genotype affects the risk for $\mathrm{AD}$ remains unresolved. It has been consistently shown that patients carrying APOE4 allele, compared with those with the other two isoforms, have more amyloid plaques, and this has been replicated in experimental AD mice (Fryer et al., 2005; Bales et al., 2009; Castellano et al., 2011). In agreement with prior studies (Bales et al., 2009; Castellano et al., 2011), our results demonstrate that APP mice expressing ApoE4 isoform have increased amyloid deposition compared with those expressing ApoE3. Furthermore, our microdialysis experiments (Fig. 5) show that, in comparison with ApoE3, expression of ApoE4 delays $\mathrm{A} \beta$ clearance, confirming a conclusion from a recent study (Castellano et al., 2011). It is unclear how ApoE affects $A \beta$ clearance from the brain. One possibility is that binding of $A \beta$ to ApoE decreases $A \beta$ aggregation and keeps $A \beta$ in a soluble form, thus facilitating its efflux out of CNS. Another possibility is that ApoE is important for $\mathrm{A} \beta$ clearance by microglia or astrocytes inside the brain (Jiang et al., 2008) or mediates $A \beta$ removal from the brain through the blood-brain barrier $(\mathrm{BBB})$. There are numerous reports demonstrating that ApoE binds $\mathrm{A} \beta$ (Wisniewski and Frangione, 1992; Strittmatter et al., 1993; LaDu et al., 1994), but it is still unclear how this binding affects $\mathrm{A} \beta$ aggregation (for review, see Kim et al., 2009; Holtzman et al., 2012). One frequently discussed possibility for these discrepancies is the use of nonphysiological lipid-free ApoE preparations in most in vitro studies (Kim et al., 2009). Recent in vitro studies have demonstrated that ApoE lipidation is essential for the clearance of the ApoE-A $\beta$ complex by receptor-mediated endocytosis (Jiang et al., 2008; Lee et al., 2012).

However, in vivo data have consistently demonstrated that the absence of ApoE decreases compact amyloid plaques in the brain (Bales et al., 1997; Holtzman et al., 2000; Fryer et al., 2003). Supporting these studies are $\mathrm{A} \beta$ clearance experiments, demonstrating that ApoE delays $A \beta$ efflux from the brain (Bell et al., 2007; Deane et al., 2008). Two recent reports demonstrated that amyloid pathology is significantly decreased by eliminating one copy of ApoE in mice expressing human ApoE4 and ApoE3 (Kim et al., 2011; Bien-Ly et al., 2012). Therefore, considering all data generated with APP/ApoE knock-out and hemizygous mice, it seems reasonable to conclude that the presence of ApoE in the brain retains $\mathrm{A} \beta$ in $\mathrm{CNS}$ and delays its clearance. In this regard, it seems difficult to reconcile the phenotype of APP/Abcal knock-out mice, which have less ApoE but more amyloid when compared with APP/ApoE knock-out mice.

A very distinctive characteristic of $\mathrm{APP} / \mathrm{Abca} 1$ knock-out mice not seen in APP/ApoE knock-out mice is decreased total plasma cholesterol, including both HDL and LDL cholesterol. In an effort to explain the differential effect of ABCA1 on the phenotype of ApoE3- and ApoE4-expressing mice, we examined the level of $\mathrm{A} \beta$ and apolipoproteins in plasma and analyzed the relationship with brain amyloid. First, we found that the level of $\mathrm{A} \beta 42$ in plasma of APP/E4 and APP/E4/Abcal ${ }^{-1+}$ is lower than in APP/E3 and APP/E4/Abca1 mice (Fig. 6B). Thus, changes of plasma $A \beta 42$ is in opposite direction of the brain $A \beta 42$ level (compare Figs. $6 B, 5 B$ ). However, since human APP is expressed in the periphery of these mice another possibility should also be considered, namely that there is different secretion of peripheral $\mathrm{A} \beta 42$ among the genotypes. Second, we demonstrate that there is a negative correlation between plasma HDL and amyloid plaques. It is possible that HDL and apolipoproteins in plasma 
have a role in $A \beta$ clearance because they can affect $A \beta$ balance on both sides of BBB. In this regard, our data are in concert with conclusions from other studies that showed proteins in plasma such as soluble LRP (lipoprotein receptor-related protein) can affect A $\beta$ clearance (Sagare et al., 2007; Sehgal et al., 2012).

The question raised by the current study is why Abcal deficiency affects more significantly APP/E4 than APP/E3 mice? In humans with $A B C A 1$ deficiency, cholesterol efflux is compromised, and as a result, HDL concentration is decreased (FrikkeSchmidt et al., 2004; Koldamova et al., 2010). Data from mice and humans have demonstrated that the concentration of ApoE4 in plasma and brain is lower than the concentrations of ApoE3 (Riddell et al., 2008; Bales et al., 2009; Gupta et al., 2011). A recent cross-sectional study demonstrated that total ApoE and ApoE4 levels were significantly lower in patients with $\mathrm{AD}$, and they further decrease as the A $\beta$ load, assessed by PET, increases (Gupta et al., 2011). Here, we demonstrate that the level of plasma HDL is decreased significantly in APP/E4 compared with APP/E3 mice and in APP/E4/Abcal ${ }^{-1+}$ compared with $\mathrm{APP} / \mathrm{E} 3 / \mathrm{Abcal}^{-1+}$ mice. Moreover, when HDL levels in APP/E4/Abcal ${ }^{-1+}$ mice were contrasted to those in APP/E3 mice, the difference was more than twofold (Fig. $6 E$ ). This result demonstrates that lack of one copy of Abcal doubles the effect of ApoE4 genotype on HDL concentration. Potentially, in humans, this could render patients expressing APOE4 allele more vulnerable to the consequences of $A B C A 1$ deficiency than ApoE3 carriers.

It has to be recognized that there are differences in lipoprotein metabolism between mice and humans. For example, HDLs are the main carrier of cholesterol in mouse plasma with levels higher than LDL cholesterol (Pendse et al., 2009). In contrast, in humans, LDLs are the predominant cholesterol-transporting particles with much higher levels of cholesterol compared with HDL (Pendse et al., 2009). The consequence is that, in the human population, LDLs or other circulating lipoproteins might be equally important for $A \beta$ clearance as are HDLs. Most studies agree that the total cholesterol (HDL plus non-HDL) is decreased in AD patients (Reitz et al., 2004, 2010; Blasko et al., 2011). A recent study demonstrated that the decreased total plasma cholesterol correlated positively to decreased plasma $\mathrm{A} \beta$ in a group of patients who converted to $\mathrm{AD}$ (Blasko et al., 2011).

In conclusion, our results clearly demonstrate that $A b c a 1$ deficiency affects significantly the phenotype of APP mice expressing human ApoE4 and has little effect on mice expressing ApoE3 isoform. Our data also indicate that APOE4 genotype is more susceptible to gene-gene interactions with negative consequences for the animal. Finally, the results presented here suggest that future therapies targeting ABCA1/ApoE expression such as LXR/RXR agonists could have a favorable effect on the outcome in ApoEe 4 carriers.

\section{References}

Alamed J, Wilcock DM, Diamond DM, Gordon MN, Morgan D (2006) Two-day radial-arm water maze learning and memory task; robust resolution of amyloid-related memory deficits in transgenic mice. Nat Protoc 1:1671-1679.

Bales KR, Verina T, Dodel RC, Du Y, Altstiel L, Bender M, Hyslop P, Johnstone EM, Little SP, Cummins DJ, Piccardo P, Ghetti B, Paul SM (1997) Lack of apolipoprotein E dramatically reduces amyloid beta-peptide deposition. Nat Genet 17:263-264.

Bales KR, Liu F, Wu S, Lin S, Koger D, DeLong C, Hansen JC, Sullivan PM, Paul SM (2009) Human APOE isoform-dependent effects on brain $\beta$-amyloid levels in PDAPP transgenic mice. J Neurosci 29:6771-6779.

Bell RD, Sagare AP, Friedman AE, Bedi GS, Holtzman DM, Deane R, Zlokovic BV (2007) Transport pathways for clearance of human Alzheimer's am- yloid beta-peptide and apolipoproteins $\mathrm{E}$ and $\mathrm{J}$ in the mouse central nervous system. J Cereb Blood Flow Metab 27:909-918.

Bien-Ly N, Gillespie AK, Walker D, Yoon SY, Huang Y (2012) Reducing human apolipoprotein $\mathrm{E}$ levels attenuates age-dependent $\mathrm{Ab}$ accumulation in mutant human amyloid precursor protein transgenic mice. J Neurosci 32:4803-4811.

Blasko I, Kemmler G, Jungwirth S, Wichart I, Weissgram S, Jellinger K, Tragl KH, Fischer P (2011) Prospective study on association between plasma amyloid $\beta-42$ and atherosclerotic risk factors. J Neural Transm 118:663-672.

Brooks-Wilson A, Marcil M, Clee SM, Zhang LH, Roomp K, van Dam M, Yu L, Brewer C, Collins JA, Molhuizen HO, Loubser O, Ouelette BF, Fichter K, Ashbourne-Excoffon KJ, Sensen CW, Scherer S, Mott S, Denis M, Martindale D, Frohlich J, et al. (1999) Mutations in ABC1 in Tangier disease and familial high-density lipoprotein deficiency. Nat Genet 22:336-345.

Castellano JM, Kim J, Stewart FR, Jiang H, DeMattos RB, Patterson BW, Fagan AM, Morris JC, Mawuenyega KG, Cruchaga C, Goate AM, Bales KR, Paul SM, Bateman RJ, Holtzman DM (2011) Human apoE isoforms differentially regulate brain amyloid-beta peptide clearance. Sci Transl Med 3:89ra57.

Cirrito JR, May PC, O’Dell MA, Taylor JW, Parsadanian M, Cramer JW, Audia JE, Nissen JS, Bales KR, Paul SM, DeMattos RB, Holtzman DM (2003) In vivo assessment of brain interstitial fluid with microdialysis reveals plaque-associated changes in amyloid- $\beta$ metabolism and half-life. J Neurosci 23:8844-8853.

Corder EH, Saunders AM, Strittmatter WJ, Schmechel DE, Gaskell PC, Small GW, Roses AD, Haines JL, Pericak-Vance MA (1993) Gene dose of apolipoprotein E type 4 allele and the risk of Alzheimer's disease in late onset families. Science 261:921-923.

Cramer PE, Cirrito JR, Wesson DW, Lee CY, Karlo JC, Zinn AE, Casali BT, Restivo JL, Goebel WD, James MJ, Brunden KR, Wilson DA, Landreth GE (2012) ApoE-directed therapeutics rapidly clear beta-amyloid and reverse deficits in AD mouse models. Science 335:1503-1506.

Deane R, Sagare A, Hamm K, Parisi M, Lane S, Finn MB, Holtzman DM, Zlokovic BV (2008) apoE isoform-specific disruption of amyloid beta peptide clearance from mouse brain. J Clin Invest 118:4002-4013.

Donkin JJ, Stukas S, Hirsch-Reinshagen V, Namjoshi D, Wilkinson A, May S, Chan J, Fan J, Collins J, Wellington CL (2010) ATP-binding cassette transporter Al mediates the beneficial effects of the liver X receptor agonist GW3965 on object recognition memory and amyloid burden in amyloid precursor protein/presenilin 1 mice. J Biol Chem 285:34144-34154.

Fitz NF, Cronican A, Pham T, Fogg A, Fauq AH, Chapman R, Lefterov I, Koldamova R (2010) Liver X receptor agonist treatment ameliorates amyloid pathology and memory deficits caused by high-fat diet in APP23 mice. J Neurosci 30:6862-6872.

Frikke-Schmidt R, Nordestgaard BG, Jensen GB, Tybjaerg-Hansen A (2004) Genetic variation in $\mathrm{ABC}$ transporter A1 contributes to HDL cholesterol in the general population. J Clin Invest 114:1343-1353.

Fryer JD, Taylor JW, DeMattos RB, Bales KR, Paul SM, Parsadanian M, Holtzman DM (2003) Apolipoprotein E markedly facilitates agedependent cerebral amyloid angiopathy and spontaneous hemorrhage in amyloid precursor protein transgenic mice. J Neurosci 23:7889-7896.

Fryer JD, Simmons K, Parsadanian M, Bales KR, Paul SM, Sullivan PM, Holtzman DM (2005) Human apolipoprotein E4 alters the amyloid- $\beta$ 40:42 ratio and promotes the formation of cerebral amyloid angiopathy in an amyloid precursor protein transgenic model. J Neurosci 25:2803-2810.

Gupta VB, Laws SM, Villemagne VL, Ames D, Bush AI, Ellis KA, Lui JK, Masters C, Rowe CC, Szoeke C, Taddei K, Martins RN; AIBL Research Group (2011) Plasma apolipoprotein E and Alzheimer disease risk: the AIBL study of aging. Neurology 76:1091-1098.

Hirsch-Reinshagen V, Maia LF, Burgess BL, Blain JF, Naus KE, McIsaac SA, Parkinson PF, Chan JY, Tansley GH, Hayden MR, Poirier J, Van Nostrand W, Wellington CL (2005) The absence of ABCA1 decreases soluble ApoE levels but does not diminish amyloid deposition in two murine models of Alzheimer disease. J Biol Chem 280:43243-43256.

Holtzman DM, Fagan AM, Mackey B, Tenkova T, Sartorius L, Paul SM, Bales K, Ashe KH, Irizarry MC, Hyman BT (2000) Apolipoprotein E facilitates neuritic and cerebrovascular plaque formation in an Alzheimer's disease model. Ann Neurol 47:739-747.

Holtzman DM, Herz J, Bu G (2012) Apolipoprotein E and apolipoprotein E 
receptors: normal biology and roles in Alzheimer disease. Cold Spring Harb Perspect Med 2:a006312.

Jiang Q, Lee CY, Mandrekar S, Wilkinson B, Cramer P, Zelcer N, Mann K, Lamb B, Willson TM, Collins JL, Richardson JC, Smith JD, Comery TA, Riddell D, Holtzman DM, Tontonoz P, Landreth GE (2008) ApoE promotes the proteolytic degradation of Abeta. Neuron 58:681-693.

Katzov H, Chalmers K, Palmgren J, Andreasen N, Johansson B, Cairns NJ, Gatz M, Wilcock GK, Love S, Pedersen NL, Brookes AJ, Blennow K, Kehoe PG, Prince JA (2004) Genetic variants of ABCA1 modify Alzheimer disease risk and quantitative traits related to beta-amyloid metabolism. Hum Mutat 23:358-367.

Kim J, Basak JM, Holtzman DM (2009) The role of apolipoprotein E in Alzheimer's disease. Neuron 63:287-303.

Kim J, Jiang H, Park S, Eltorai AE, Stewart FR, Yoon H, Basak JM, Finn MB, Holtzman DM (2011) Haploinsufficiency of human APOE reduces amyloid deposition in a mouse model of amyloid- $\beta$ amyloidosis. J Neurosci 31:18007-18012.

Koldamova RP, Lefterov IM, Lefterova MI, Lazo JS (2001) Apolipoprotein A-I directly interacts with amyloid precursor protein and inhibits A beta aggregation and toxicity. Biochemistry 40:3553-3560.

Koldamova RP, Lefterov IM, Staufenbiel M, Wolfe D, Huang S, Glorioso JC, Walter M, Roth MG, Lazo JS (2005a) The liver X receptor ligand T0901317 decreases amyloid $\beta$ production in vitro and in a mouse model of Alzheimer's disease. J Biol Chem 280:4079-4088.

Koldamova R, Staufenbiel M, Lefterov I (2005b) Lack of ABCA1 considerably decreases brain ApoE level and increases amyloid deposition in APP23 mice. J Biol Chem 280:43224-43235.

Koldamova R, Fitz NF, Lefterov I (2010) The role of ATP-binding cassette transporter Al in Alzheimer's disease and neurodegeneration. Biochim Biophys Acta 1801:824-830.

Kornecook TJ, McKinney AP, Ferguson MT, Dodart JC (2010) Isoformspecific effects of apolipoprotein $\mathrm{E}$ on cognitive performance in targetedreplacement mice overexpressing human APP. Genes Brain Behav 9:182-192.

LaDu MJ, Falduto MT, Manelli AM, Reardon CA, Getz GS, Frail DE (1994) Isoform-specific binding of apolipoprotein $\mathrm{E}$ to beta-amyloid. J Biol Chem 269:23403-23406.

Lee CY, Tse W, Smith JD, Landreth GE (2012) Apolipoprotein E promotes beta-amyloid trafficking and degradation by modulating microglial cholesterol levels. J Biol Chem 287:2032-2044.

Lefterov I, Fitz NF, Cronican A, Lefterov P, Staufenbiel M, Koldamova R (2009) Memory deficits in APP23/Abcal ${ }^{+-}$mice correlate with the level of Abeta oligomers. ASN Neuro 1:pii:e00006.

Lefterov I, Fitz NF, Cronican AA, Fogg A, Lefterov P, Kodali R, Wetzel R, Koldamova R (2010) Apolipoprotein A-I deficiency increases cerebral amyloid angiopathy and cognitive deficits in APP/PS1DeltaE9 mice. J Biol Chem 285:36945-36957.

Lewis TL, Cao D, Lu H, Mans RA, Su YR, Jungbauer L, Linton MF, Fazio S, LaDu MJ, Li L (2010) Overexpression of human apolipoprotein A-I preserves cognitive function and attenuates neuroinflammation and cerebral amyloid angiopathy in a mouse model of Alzheimer disease. J Biol Chem 285:36958-36968.

Li Y, Tacey K, Doil L, van Luchene R, Garcia V, Rowland C, Schrodi S, Leong D, Lau K, Catanese J, Sninsky J, Nowotny P, Holmans P, Hardy J, Powell J, Lovestone S, Thal L, Owen M, Williams J, Goate A, et al. (2004) Association of ABCA1 with late-onset Alzheimer's disease is not observed in a case-control study. Neurosci Lett 366:268-271.

Pendse AA, Arbones-Mainar JM, Johnson LA, Altenburg MK, Maeda N (2009) Apolipoprotein E knock-out and knock-in mice: atherosclerosis, metabolic syndrome, and beyond. J Lipid Res [50 Suppl]:S178-S182.

Puzzo D, Privitera L, Leznik E, Fà M, Staniszewski A, Palmeri A, Arancio O (2008) Picomolar amyloid- $\beta$ positively modulates synaptic plasticity and memory in hippocampus. J Neurosci 28:14537-14545.

Reitz C, Tang MX, Luchsinger J, Mayeux R (2004) Relation of plasma lipids to Alzheimer disease and vascular dementia. Arch Neurol 61:705-714.
Reitz C, Tang MX, Schupf N, Manly JJ, Mayeux R, Luchsinger JA (2010) Association of higher levels of high-density lipoprotein cholesterol in elderly individuals and lower risk of late-onset Alzheimer disease. Arch Neurol 67:1491-1497.

Reynolds CA, Hong MG, Eriksson UK, Blennow K, Bennet AM, Johansson B, Malmberg B, Berg S, Wiklund F, Gatz M, Pedersen NL, Prince JA (2009) A survey of $A B C A 1$ sequence variation confirms association with dementia. Hum Mutat 30:1348-1354.

Riddell DR, Zhou H, Atchison K, Warwick HK, Atkinson PJ, Jefferson J, Xu L, Aschmies S, Kirksey Y, Hu Y, Wagner E, Parratt A, Xu J, Li Z, Zaleska MM, Jacobsen JS, Pangalos MN, Reinhart PH (2008) Impact of apolipoprotein $E$ (ApoE) polymorphism on brain ApoE levels. J Neurosci 28:11445-11453.

Sagare A, Deane R, Bell RD, Johnson B, Hamm K, Pendu R, Marky A, Lenting PJ, Wu Z, Zarcone T, Goate A, Mayo K, Perlmutter D, Coma M, Zhong Z, Zlokovic BV (2007) Clearance of amyloid-beta by circulating lipoprotein receptors. Nat Med 13:1029-1031.

Saunders AM, Strittmatter WJ, Schmechel D, George-Hyslop PH, Pericak-Vance MA, Joo SH, Rosi BL, Gusella JF, Crapper-MacLachlan DR, Alberts MJ (1993) Association of apolipoprotein E allele epsilon 4 with late-onset familial and sporadic Alzheimer's disease. Neurology 43:1467-1472.

Sehgal N, Gupta A, Valli RK, Joshi SD, Mills JT, Hamel E, Khanna P, Jain SC, Thakur SS, Ravindranath V (2012) Withania somnifera reverses Alzheimer's disease pathology by enhancing low-density lipoprotein receptorrelated protein in liver. Proc Natl Acad Sci U S A 109:3510-3515.

Shibata N, Kawarai T, Lee JH, Lee HS, Shibata E, Sato C, Liang Y, Duara R, Mayeux RP, St George-Hyslop PH, Rogaeva E (2006) Association studies of cholesterol metabolism genes $(\mathrm{CH} 25 \mathrm{H}, \mathrm{ABCA} 1$ and $\mathrm{CH} 24 \mathrm{H})$ in Alzheimer's disease. Neurosci Lett 391:142-146.

Strittmatter WJ, Saunders AM, Schmechel D, Pericak-Vance M, Enghild J, Salvesen GS, Roses AD (1993) Apolipoprotein E: high-avidity binding to beta-amyloid and increased frequency of type 4 allele in late-onset familial Alzheimer disease. Proc Natl Acad Sci U S A 90:1977-1981.

Sullivan PM, Mezdour H, Aratani Y, Knouff C, Najib J, Reddick RL, Quarfordt SH, Maeda N (1997) Targeted replacement of the mouse apolipoprotein E gene with the common human APOE3 allele enhances diet-induced hypercholesterolemia and atherosclerosis. J Biol Chem 272:17972-17980.

Sundar PD, Feingold E, Minster RL, DeKosky ST, Kamboh MI (2007) Gender-specific association of ATP-binding cassette transporter 1 (ABCA1) polymorphisms with the risk of late-onset Alzheimer's disease. Neurobiol Aging 28:856-862.

Wahrle SE, Jiang H, Parsadanian M, Legleiter J, Han X, Fryer JD, Kowalewski $\mathrm{T}$, Holtzman DM (2004) ABCA1 is required for normal central nervous system ApoE levels and for lipidation of astrocyte-secreted apoE. J Biol Chem 279:40987-40993.

Wahrle SE, Jiang H, Parsadanian M, Hartman RE, Bales KR, Paul SM, Holtzman DM (2005) Deletion of Abcal increases $A \beta$ deposition in the PDAPP transgenic mouse model of Alzheimer disease. J Biol Chem 280:43236-43242.

Wahrle SE, Shah AR, Fagan AM, Smemo S, Kauwe JS, Grupe A, Hinrichs A, Mayo K, Jiang H, Thal LJ, Goate AM, Holtzman DM (2007) Apolipoprotein E levels in cerebrospinal fluid and the effects of ABCA1 polymorphisms. Mol Neurodegener 2:7.

Wahrle SE, Jiang H, Parsadanian M, Kim J, Li A, Knoten A, Jain S, HirschReinshagen V, Wellington CL, Bales KR, Paul SM, Holtzman DM (2008) Overexpression of ABCA1 reduces amyloid deposition in the PDAPP mouse model of Alzheimer disease. J Clin Invest 118:671-682.

Wisniewski T, Frangione B (1992) Apolipoprotein E: a pathological chaperone protein in patients with cerebral and systemic amyloid. Neurosci Lett 135:235-238.

Wollmer MA, Streffer JR, Lütjohann D, Tsolaki M, Iakovidou V, Hegi T, Pasch T, Jung HH, Bergmann K, Nitsch RM, Hock C, Papassotiropoulos A (2003) ABCA1 modulates CSF cholesterol levels and influences the age at onset of Alzheimer's disease. Neurobiol Aging 24:421-426. 